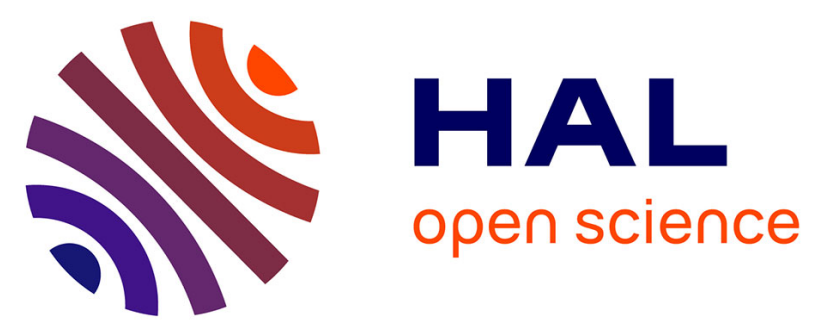

\title{
High-resolution reconstruction of atmospheric deposition of trace metals and metalloids since AD 1400 recorded by ombrotrophic peat cores in Hautes-Fagnes, Belgium
}

Mohammed Allan, Gaël Le Roux, François de Vleeschouwer, Richard Bindler, Maarten Blaauw, Natalia Piotrowska, Jaroslaw Sikorski, Nathalie Fagel

\section{To cite this version:}

Mohammed Allan, Gaël Le Roux, François de Vleeschouwer, Richard Bindler, Maarten Blaauw, et al.. High-resolution reconstruction of atmospheric deposition of trace metals and metalloids since AD 1400 recorded by ombrotrophic peat cores in Hautes-Fagnes, Belgium. Environmental Pollution, 2013, vol. 178, pp.381-394. 10.1016/j.envpol.2013.03.018 . hal-00977497

\section{HAL Id: hal-00977497 \\ https://hal.science/hal-00977497}

Submitted on 11 Apr 2014

HAL is a multi-disciplinary open access archive for the deposit and dissemination of scientific research documents, whether they are published or not. The documents may come from teaching and research institutions in France or abroad, or from public or private research centers.
L'archive ouverte pluridisciplinaire $\mathbf{H A L}$, est destinée au dépôt et à la diffusion de documents scientifiques de niveau recherche, publiés ou non, émanant des établissements d'enseignement et de recherche français ou étrangers, des laboratoires publics ou privés. 


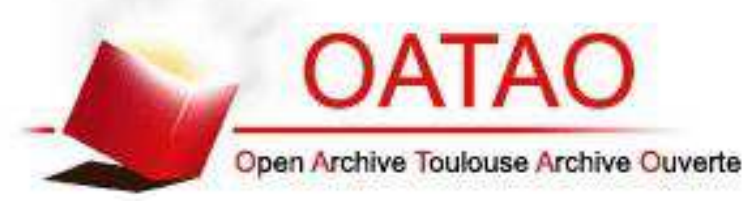

\section{Open Archive TOULOUSE Archive Ouverte (OATAO)}

OATAO is an open access repository that collects the work of Toulouse researchers and makes it freely available over the web where possible.

This is an author-deposited version published in : http://oatao.univ-toulouse.fr/ Eprints ID : 11360

To link to this article :

DOI:10.1016/j.envpol.2013.03.018

URL : http://dx.doi.org/10.1016/j.envpol.2013.03.018

\section{To cite this version :}

Allan, Mohammed and Le Roux, Gaël and De Vleeschouwer, François and Bindler, Richard and Blaauw, Maarten and Piotrowska, Natalia and Sikorski, Jaroslaw and Fagel, Nathalie High-resolution reconstruction of atmospheric deposition of trace metals and metalloids since AD 1400 recorded by ombrotrophic peat cores in Hautes-Fagnes, Belgium. (2013) Environmental Pollution, vol. 178 . pp. 381-394. ISSN 0269-7491

Any correspondance concerning this service should be sent to the repository administrator: staff-oatao@ listes-diff.inp-toulouse.fr 


\title{
High-resolution reconstruction of atmospheric deposition of trace metals and metalloids since AD 1400 recorded by ombrotrophic peat cores in Hautes-Fagnes, Belgium
}

\author{
Mohammed Allan ${ }^{\mathrm{a}, *}$, Gaël Le Roux ${ }^{\mathrm{b}, \mathrm{c}}$, François De Vleeschouwer ${ }^{\mathrm{b}, \mathrm{c}}$, Richard Bindler ${ }^{\mathrm{d}}$, \\ Maarten Blaauw ${ }^{\mathrm{e}}$, Natalia Piotrowska ${ }^{\mathrm{f}}$, Jaroslaw Sikorski $^{\mathrm{f}}$, Nathalie Fagel $^{\mathrm{a}}$ \\ a AGEs, Département de Géologie, Université de Liège, Allée du 6 Août, B18 Sart Tilman B-4000, Liège, Belgium \\ ${ }^{\mathrm{b}}$ Université de Toulouse, INP, UPS, EcoLab (Laboratoire Ecologie Fonctionnelle et Environnement), ENSAT, Avenue de l'Agrobiopole, 31326 Castanet Tolosan, \\ France \\ ${ }^{\mathrm{c}}$ CNRS, EcoLab, 31326 Castanet Tolosan, France \\ ${ }^{\mathrm{d}}$ Department of Ecology and Environmental Science, Umeå University, KBC Building, 90187 Umeå, Sweden \\ e School of Geography, Archaeology Er Palaeoecology, Queen's University Belfast, UK \\ ${ }^{\mathrm{f}}$ Department of Radioisotopes, GADAM Centre of Excellence, Institute of Physics, Silesian University of Technology, Gliwice, Poland
}

\section{Keywords:}

Atmospheric pollution

Industrial Revolution

Trace metals

Lead isotopes

Misten bog

\begin{abstract}
A B S T R A C T
The objective of our study was to determine the trace metal accumulation rates in the Misten bog, Hautes-Fagnes, Belgium, and assess these in relation to established histories of atmospheric emissions from anthropogenic sources. To address these aims we analyzed trace metals and metalloids $(\mathrm{Pb}, \mathrm{Cu}, \mathrm{Ni}$, $\mathrm{As}, \mathrm{Sb}, \mathrm{Cr}, \mathrm{Co}, \mathrm{V}, \mathrm{Cd}$ and $\mathrm{Zn}$ ), as well as Pb isotopes, using XRF, Q-ICP-MS and MC-ICP-MS, respectively in two $40-\mathrm{cm}$ peat sections, spanning the last $600 \mathrm{yr}$. The temporal increase of metal fluxes from the inception of the Industrial Revolution to the present varies by a factor of 5-50, with peak values found between AD 1930 and 1990. A cluster analysis combined with $\mathrm{Pb}$ isotopic composition allows the identification of the main sources of $\mathrm{Pb}$ and by inference of the other metals, which indicates that coal consumption and metallurgical activities were the predominant sources of pollution during the last 600 years.
\end{abstract}

\section{Introduction}

Trace metals and metalloids (referred here as trace metals) have been dispersed into the environment by human activities since the beginning of metallurgy (Nriagu, 1996). The increased in atmospheric deposition of trace metals compared to prehistoric levels is marked in the northern Hemisphere, particularly in Europe since at least 2000 years (Renberg et al., 1994; Hong et al., 1994), Mining and metallurgical activities, and later also coal burning and transport emissions were the principal anthropogenic sources (Nriagu, 1979; Pacyna and Pacyna, 2001; Pacyna et al., 2007; Shotyk and Le Roux, 2005). At present, soil contamination by atmospheric deposition can be expressed as a sum of local contamination by past and on-going human activities and by long-range atmospheric transport of trace metals. The magnitude and timing of changes in

\footnotetext{
* Corresponding author.

E-mail addresses: mallan@doct.ulg.ac.be, mouhamdallan@hotmail.fr (M. Allan).
}

atmospheric trace metals deposition have been studied in a variety of environmental archives. Peat records from ombrotrophic bogs can provide valuable information about the atmospheric inputs of trace metals (e.g., Shotyk et al., 1996; Martinez-Cortizas et al., 1997; Farmer et al., 2009), because they are fed with nutrients and pollutants only through atmospheric inputs. Ombrotrophic peatlands could also store a faithful signal (i.e. no significant postdepositional remobilization) of the changing deposition, and thus of the content of elements/compounds in the atmosphere (Gore, 1983; Damman, 1986; Shotyk et al., 2001, 2002).

The evolution of the current accumulation of heavy metals in the environment my help to establish the magnitude and nature of the anthropogenic sources. Records of trace metals in bogs indicate that the Industrial Revolution marked a time of enhanced atmospheric pollution, caused by mining, fossil fuel combustion, agriculture, industry, urban development, and vehicle traffic (e.g., MartinezCortizas et al.,1997; Shotyk et al.,1998; De Vleeschouwer et al., 2009). To assess the extent of atmospheric contamination, it is necessary to identify the main past and present sources of trace metal emissions. 
Not only atmospheric deposition of trace metals with established environmental concern, such as cadmium, lead and mercury (Pontevedra-Pombal et al., 2013), should be investigated, but also other metals with recent increased use and emission such as antimony (Shotyk et al., 2005a).

The mobility of metal and metalloid elements may be due to various factors such as adsorption on oxy-hydroxides and variations in $\mathrm{pH}$ (e.g., Rausch et al., 2005a,b), or uptake and recycling by plants (e.g., Damman, 1978; MacKenzie et al., 1998). Numerous studies demonstrated that $\mathrm{Pb}$ is an immobile element in ombrotrophic bog based on stable and radioactive $\mathrm{Pb}$ isotopes, $\mathrm{Pb}$ profiles in porewaters comparison with rain collectors and herbarium samples and transplant experiments (e.g. Shotyk et al., 2001; Weiss et al., 2002; Farmer et al., 2002; Le Roux et al., 2005; Novak et al., 2011). However, some investigations also demonstrated that $\mathrm{Pb}$ can be affected by diagenetic remobilization and redistribution processes in saturated peats (e.g., MacKenzie et al., 1998; Olid et al., 2010). Zinc is often associated to $\mathrm{Pb}$ in sulfide minerals (including galena) and coals (Shotyk et al., 2003, 2005). However, Zn behavior is different to that of $\mathrm{Pb}$ in ombrotrophic bog. In contrast to the immobility of $\mathrm{Pb}, \mathrm{Zn}$ can be mobile due to bioaccumulation, redistribution by plants, and $\mathrm{pH}$ conditions (Damman, 1978; Kempter and Frenzel, 1999; Livett et al., 1979; Novak and Pacherova, 2008). Rausch et al. (2005a,b) studied three peat cores from Finnish bogs and found that $\mathrm{Cd}$ is mobile and affected by post-depositional processes, while Co was immobile. Compared to $\mathrm{Pb}$ and $\mathrm{Zn}, \mathrm{Cu}$ has been less studied in ombrotrophic bog. Nieminen et al. (2002) showed that $\mathrm{Cu}$ could be preserved in a peat record in close proximity to a major smelter, whereas Shotyk et al. (2002) and Ukonmaanaho et al. (2004) found that $\mathrm{Cu}$ could be affected to some extent by plant uptake like Zn. Rausch et al. (2005a,b) suggested that the $\mathrm{pH}$ and mineralogy controlled the $\mathrm{Cu}$ mobility in peat. Recently, Novak et al. (2011) demonstrated that $\mathrm{Pb}, \mathrm{Cu}$ and $\mathrm{Zn}$ were immobile in two peat cores collected in the Czech Republic. Bergkvist et al. (1989) and Kabata-Pendias (2001) argued that Ni can form relatively weak complexes with organic matter and that its mobility is strongly related to pH. Kabata-Pendias (2001) showed that $\mathrm{Ni}$ is generally a mobile element in organic substrates. Similarly, Ukonmaanaho et al. (2004) found that Ni is mobile and affected by leaching in the recent ombrotrophic bog. In contrast, Krachler et al. (2003) considered that Ni was effectively immobile in ombrotrophic bog on a longer time scale $(10,000$ years). Very few studies have been performed on the behavior of As, $\mathrm{Sb}, \mathrm{V}, \mathrm{Cr}$, Co and Cd in ombrotrophic bog (Rausch et al., 2005a,b; Cloy et al., 2009; Rothwell et al., 2010; Shotyk et al., 2004). A multicoring approach (Cloy et al., 2009) was used to show that As and $\mathrm{Sb}$ are also relatively immobile elements in ombrotrophic bogs, but As mobility can be affected by the nature of organic matter, variability in the groundwater table and by presence of Fe oxides (e.g. Rothwell et al., 2009; Buschmann et al., 2006). Cerqueira et al. (2012) showed that $\mathrm{Cr}$ mobility is controlled by pH. In a Swiss bog, Krachler et al. (2003) considered that $\mathrm{V}$ and $\mathrm{Cr}$ abundances are due to the anthropogenic emissions and are not affected by plant uptake or diagenesis processes.

Here we investigated two peat cores from the Misten bog, an ombrotrophic bog in Belgium, with a special focus on the last 600 years. We determined the chemical depth-profiles of $\mathrm{V}, \mathrm{Cr}, \mathrm{Co}, \mathrm{Ni}$, $\mathrm{Cu}, \mathrm{Zn}, \mathrm{As}, \mathrm{Pb}, \mathrm{Cd}, \mathrm{Sb}$ and stable $\mathrm{Pb}$ isotopes in a high-resolution peat sequence in order to investigate the possible mobility of trace metals. To address this question we compared the records of selected elements $(\mathrm{V}, \mathrm{Cr}, \mathrm{Ni}, \mathrm{Cu}, \mathrm{Zn}$, and $\mathrm{Pb})$ in two cores sampled at different microtopographical units (one in a hummock and another in a hummock-hollow transition), and with other records from the same area (De Vleeschouwer et al., 2007) and elsewhere in Western Europe. Furthermore, by coupling cluster analyses and $\mathrm{Pb}$ isotopes, we aimed to identify trace metal relationships and sources over the last 600 years.

\section{Material and methods}

\subsection{Site description}

The Misten bog is located in the Hautes-Fagnes Plateau, in eastern Belgium (Fig. 1). This Plateau is located close to $\mathrm{Pb}-\mathrm{Zn}$ ore deposits that have been exploited since the Roman Empire (Renson et al., 2008) to ca. AD 1945 (Dejonghe, 1998). The bog surface is elevated above the surrounding terrain. The maximum peat thickness reaches up to $8 \mathrm{~m}$ (Wastiaux and Schumacker, 2003) and the complete peat deposit section spans $\sim 9000$ years (De Vleeschouwer et al., 2007).

Two cores were retrieved in February 2008 (Fig. 1), using a titanium Wardenaar corer (Wardenaar, 1987). The two cores, designated MIS-08-01W (01W) collected from a hummock and MIS-08-06W (06W) taken between a hummock and a hollow have a length of $100 \mathrm{~cm}$ and a square section of $15 \mathrm{by} 15 \mathrm{~cm}$. Core sub-sampling was adapted from Givelet et al. (2004) and De Vleeschouwer et al. (2010a). The core 06W was previously studied by De Vleeschouwer et al. (2010b, 2012) for its chronology, atmospheric dust flux and palaeoenvironmental changes. In this paper, we focus on the upper $40 \mathrm{~cm}$ of both cores and their trace metal content.

\subsection{Elemental geochemistry and $\mathrm{Pb}$ isotope analyses}

Because the two cores were initially part of two different studies, the samples from each one were analyzed separately using different methods.

\subsubsection{MIS-08-01W core}

Peat samples were digested by microwave autoclave at the Institute of Earth Sciences (University of Heidelberg) using a mixture of $\mathrm{HNO}_{3}(3 \mathrm{ml})$ and $\mathrm{HBF}_{4}(0.1 \mathrm{ml})$ according to Krachler et al. (2002). The digestion of organic matter was improved by an addition of $\mathrm{H}_{2} \mathrm{O}_{2}$ in the reaction chamber (Krachler et al., 2002). After digestion, $\sim 3 \mathrm{ml}$ of solution were poured into a Falcon tube and filled up to $14 \mathrm{ml}$.

A first aliquot was used to measure the concentrations of trace elements, as well as lithogenic and conservative elements $\mathrm{Al}$, Sc, and Ti. These elements were measured by Quadrupole Inductively Coupled Plasma Mass Spectroscopy (Q-ICPMS, 7500 ce, Agilent Technologies), at the Observatoire Midi-Pyrénées, Toulouse, France, after adequate dilution and spiking with a standard In-Re for interna normalization processes. Three certified reference materials (ICHTJ CTA-OTL-1 Oriental Tobacco Leaves, NIST Tomato Leaves 1573 and IAEA Lichen 336) were analyzed with each series of samples, in order to determine the precision and accuracy of analytical procedures. Comparison between reference values and measured values were satisfactory (Table 1 ) within $88-97 \%$. For V, Cr, Co, Ni, Cu, Zn, As, Pb and Cd, the reproducibility was higher than $92 \%$. The lowest value was observed for $\mathrm{Sb}$ ( $87 \%$ for Tobacco leaves CTA-OTL standard).

A second aliquot was used to measure the $\mathrm{Pb}$ isotopic composition (Table 2). The dried samples were dissolved in a mixture of concentrated $\mathrm{HNO}_{3}$ and $\mathrm{HF}$ in a proportion of $1: 4$ and heated at $125^{\circ} \mathrm{C}$ for $48 \mathrm{~h}$. After drying, $2 \mathrm{ml}$ of $6 \mathrm{M} \mathrm{HCl}$ were added to ensure complete digestion and the solutions were evaporated. For separation of $\mathrm{Pb}$ isotopes and REE (e.g., $\mathrm{La}, \mathrm{Ce}, \mathrm{Nd}, \mathrm{Nd}$ ), the samples were dissolved in $0.5 \mathrm{ml}$ of $0.8 \mathrm{M} \mathrm{HBr}$ and passed on Teflon column filled with AG1-X8 resin. The Pb isotopic ratios were measured using an MC-ICP-MS (Multi Collector-Inductively Coupled plasma Mass Spectrometry, Nu plasma), at the Department of Earth and Environment Sciences, Université Libre de Bruxelles. The mass fractionation was internally corrected for mass bias using the known ${ }^{205} \mathrm{Tl} /{ }^{203} \mathrm{Tl}$ ratio (Thirlwall, 2002). During the analysis, the Pb NBS981 standard was repeatedly measured in alternation with samples in order to control any daily instrument drift. The isotope ratios of the NBS981 standard were stable during the three analysis sessions $[n=41$ ${ }^{208} \mathrm{~Pb} /{ }^{204} \mathrm{~Pb}=36.713 \pm 0.0032(2 \sigma),{ }^{207} \mathrm{~Pb} /{ }^{204} \mathrm{~Pb}=15.4958 \pm 0.0012(2 \sigma)$, $\left.{ }^{206} \mathrm{~Pb} /{ }^{204} \mathrm{~Pb}=16.9390 \pm 0.0012(2 \sigma)\right]$. NBS981 values are in agreement with the long-term laboratory value $\left[n=1000,{ }^{208} \mathrm{~Pb} /{ }^{204} \mathrm{~Pb}=36.7130 \pm 0.012(2 \sigma)\right.$ $\left.{ }^{207} \mathrm{~Pb} /{ }^{204} \mathrm{~Pb}=15.4950 \pm 0.004(2 \sigma),{ }^{206} \mathrm{~Pb} /{ }^{204} \mathrm{~Pb}=16.9393 \pm 0.0044(2 \sigma)\right]$, and they are also comparable to the reference values reported in the literature (e.g., Renson et al., 2008; Galer and Abouchami, 1998).

\subsubsection{MIS-08-06W core}

The concentrations of selected major and trace elements ( $\mathrm{Al}, \mathrm{Ti}, \mathrm{Ni}, \mathrm{Cu}, \mathrm{Zn}, \mathrm{Pb}$ ) were measured on $2 \mathrm{~g}$ of dried and homogenized powder using a Bruker S8 Tiger wavelength-dispersive X-Ray Fluorescence (WD-XRF) analyzer equipped with a Rh anticathode X-ray tube. Powders were transferred in 40-mm opening plastic cups with a $2.5-\mu \mathrm{m}$ Mylar film at the base. After that they were placed in metallic cup holders for analysis using a $34 \mathrm{~mm}$ mask. A specific calibration was developed in order to optimize the WD-XRF for the matrices of the samples (De Vleeschouwer et al., 2012). This was achieved using 27 certified reference materials, consisting of tree and vegetable leaves (NIST1515, NIST1547, NIST1570a, NIST1573a, BCR62, NIES1, NIES7), pine needles (NIST1575a), wheat flour (NIST8437, NIST8438), rice flour (NIES10a, NIES10b, NIES10c), lichen (BCR482), aquatic plants (BCR60, NIES3, NIES9), peat (NIMT-UOE-FM-001, NJV94-2), wood (NJV94-3), hay powder (BCR129), milk 


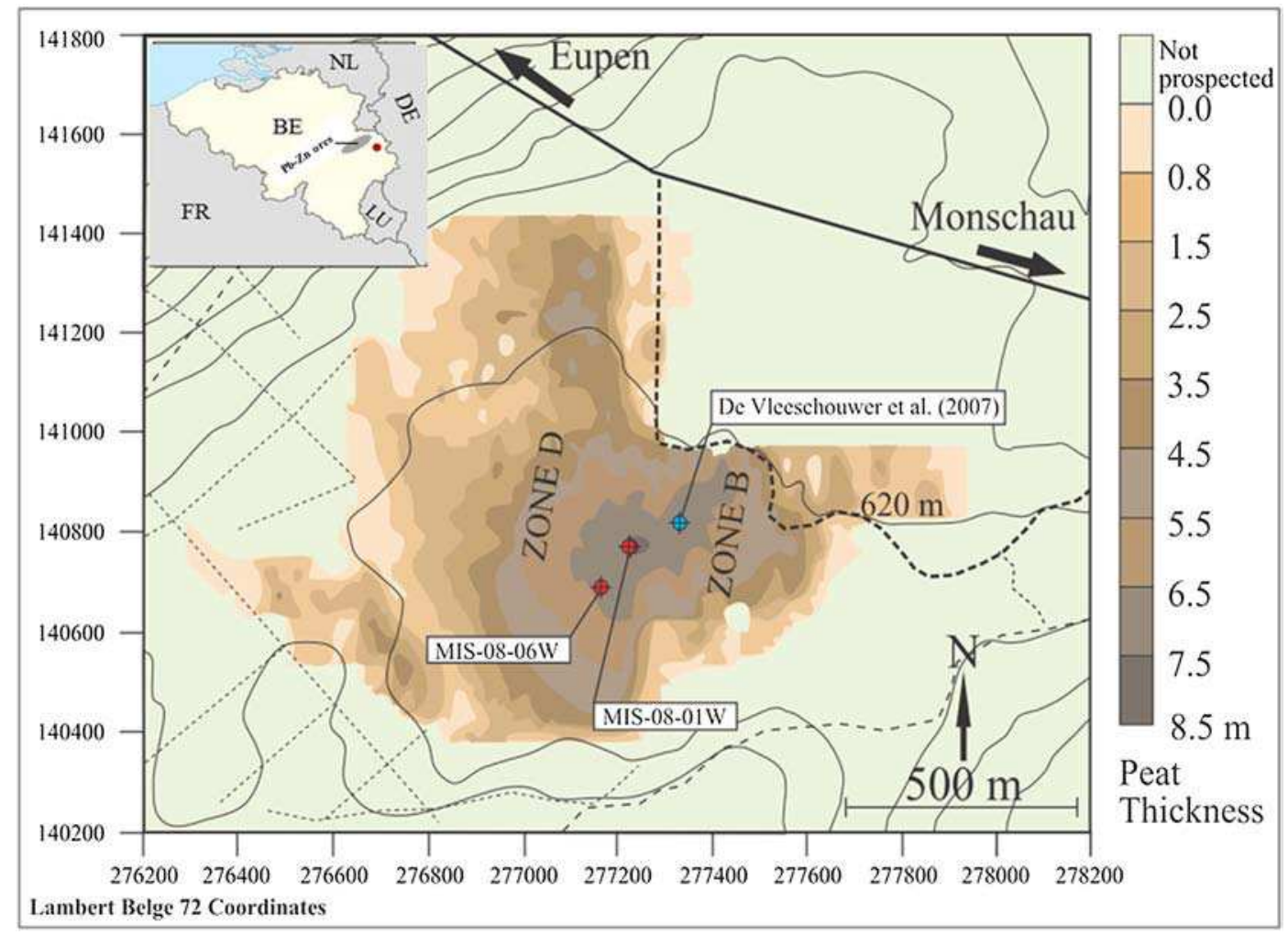

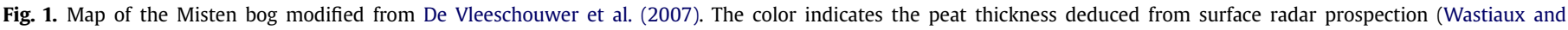

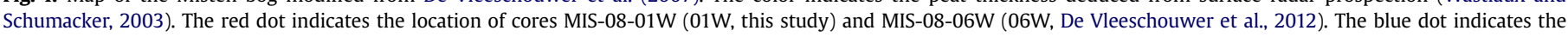

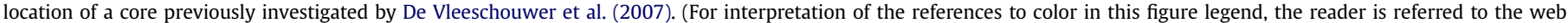
version of this article.)

powder (BCR150), coal (NIST1632b, NIST1635, SARM20), coke (NIST2718) and vehicle exhaust particles (NIES8). This selection is based on the certified values available in each CRM, which are matched with the expected detectable concentrations of our WD-XRF spectrometer. The last 3 CRM categories were included to extend the range of various trace elements. An internal standard was measured daily to check the analytical performance of the XRF. Three additional internal standards were used to monitor the long-term (yearly) drift of the device and to correct intensities if necessary. Results, as well as detection limits and standard deviations are reported in Table 3.

\subsection{Chronology}

For both cores, radiocarbon ages ( 6 samples for $01 \mathrm{~W}$ and 22 samples for $06 \mathrm{~W}$ ) were obtained on aboveground plant macrofossils extracted following the methods described in Kilian et al. (1995) and Mauquoy et al. (2004). Samples were purified and graphitized prior to Acceleration Mass Spectrometry (AMS) measurement, at the GADAM Center for Excellence (University of Gliwice, Poland) following the protocol defined by Piotrowska et al. $(2010,2011)$. Activities of ${ }^{210} \mathrm{~Pb}$ were indirectly determined by the measurement of its decay product ${ }^{210} \mathrm{Po}$ using an alpha spectrometer (Canberra 740) according to the protocol detailed in Sikorski and Bluszcz (2008) and De Vleeschouwer et al. (2010b). The ${ }^{14} \mathrm{C}$ and ${ }^{210} \mathrm{~Pb}$ data and the age model for core 01W are reported in Allan et al. (2012), while the age model of 06W is reported in De Vleeschouwer et al. (2012). We used the Bacon age-depth modeling routines (Blaauw and Christen, 2011) to establish a coherent evolution of deposition along the core depth, and possibly including some sections where discontinuities are suspected (hiatuses). In this paper, we apply these age models to plot proxy vs. depth diagrams (Figs. 2,4), where the calendar scale uncertainties are also indicated using gray-scales. The age-depth models show that peat accumulation is non-linear. Moreover, peat profiles which are situated close together, such as $01 \mathrm{~W}$ and $06 \mathrm{~W}$, may exhibit very different growth rates. Regarding the last 600 years, the mean peat accumulation rate varies between 0.02 and $0.09 \mathrm{~cm} \mathrm{yr}^{-1}$ for $01 \mathrm{~W}$ (from 40 to $17 \mathrm{~cm}$ ), and for $06 \mathrm{~W}$ between 0.03 and 0.08 (from 40 to $10 \mathrm{~cm}$ ). Above $17 \mathrm{~cm}$ for $01 \mathrm{~W}$ and $10 \mathrm{~cm}$ for $06 \mathrm{~W}$, and until the top, the accumulation rate increases drastically (AR 0.1-1.3) and marks the progressive shift from the catotelm to the acrotelm, characterized by living plants and uncompressed peat. The section of each of the two peat cores studied in further detail here span the period from ca. AD 1400 to the present.

\subsection{Calculation of enrichment factors}

The variation in trace metal concentrations can be explained by changes in supply, changes in their origin (natural or anthropogenic sources), and differences in peat mass accumulation and the quantity of mineral material in the peat. One approach to separate the influence of anthropogenic sources from natural mineral matter is to calculate an enrichment factor for each metal by using a conservative element indicative of mineral matter, such as Ti. Mineral contribution to the bogs

Table 1

Comparison between reference and measured values for three certified reference materials.

\begin{tabular}{|c|c|c|c|c|c|c|}
\hline Standard & Element $\left(\mu g^{-1}\right)$ & $\mathrm{Cu}$ & $\mathrm{Pb}$ & $\mathrm{Zn}$ & Mo & $\mathrm{Sb}$ \\
\hline \multirow[t]{3}{*}{ CTA-OTL } & Reference values & $14.1 \pm 0.5$ & $4.91 \pm 0.8$ & $49.9 \pm 2.4$ & 0.26 & 0.075 \\
\hline & Mean measured values $(n=6)$ & $13.4 \pm 0.7$ & $4.33 \pm 0.3$ & $46.3 \pm 3.2$ & $0.30 \pm 0.02$ & $0.065 \pm 0.007$ \\
\hline & Reproducibility (\%) & 94 & 92 & 92 & 93 & 87 \\
\hline \multirow[t]{3}{*}{ Lichen IAEA 336} & Reference values & $3.6 \pm 0.5$ & $4.90 \pm 0.6$ & $30.4 \pm 3.4$ & - & $0.070 \pm 0.01$ \\
\hline & Mean measured values $(n=4)$ & $2.9 \pm 0.1$ & $4.07 \pm 0.1$ & $25.6 \pm 0.9$ & - & $0.078 \pm 0.004$ \\
\hline & Reproducibility (\%) & 96 & 97 & 96 & - & 94 \\
\hline \multirow[t]{3}{*}{ Tomato leaves 1573} & Reference values & 4.7 & - & - & 0.46 & - \\
\hline & Mean measured values $(n=2)$ & $4.6 \pm 0.2$ & - & - & $0.41 \pm 0.006$ & - \\
\hline & Reproducibility (\%) & 100 & - & - & 98 & - \\
\hline
\end{tabular}


Table 2

$\mathrm{Pb}$ isotopic ratios measured by MC-ICP-MS Nu Plasma and standard deviations.

\begin{tabular}{|c|c|c|c|c|c|c|c|c|c|c|}
\hline Depth $(\mathrm{cm})$ & ${ }^{208} \mathrm{~Pb} /{ }^{204} \mathrm{~Pb}$ & $2 \sigma$ & ${ }^{207} \mathrm{~Pb} /{ }^{204} \mathrm{~Pb}$ & $2 \sigma$ & ${ }^{206} \mathrm{~Pb} /{ }^{204} \mathrm{~Pb}$ & $2 \sigma$ & ${ }^{208} \mathrm{~Pb} /{ }^{206} \mathrm{~Pb}$ & $2 \sigma$ & ${ }^{206} \mathrm{~Pb} /{ }^{207} \mathrm{~Pb}$ & $2 \sigma$ \\
\hline 2.2 & 38.00507 & 0.00252 & 15.63637 & 0.00095 & 18.29126 & 0.00105 & 2.07783 & 0.000044 & 1.16977 & 0.000012 \\
\hline 6.5 & 37.89126 & 0.00216 & 15.62515 & 0.00086 & 18.18608 & 0.00095 & 2.08356 & 0.000034 & 1.16388 & 0.000012 \\
\hline 10.1 & 37.87916 & 0.002 & 15.60458 & 0.00077 & 18.01815 & 0.00087 & 2.10232 & 0.000038 & 1.15466 & 0.000014 \\
\hline 11.9 & 37.88852 & 0.00117 & 15.59218 & 0.00036 & 17.95033 & 0.0004 & 2.11073 & 0.000046 & 1.15125 & 0.000013 \\
\hline 13.7 & 37.89525 & 0.00218 & 15.59351 & 0.00089 & 17.95328 & 0.00107 & 2.11075 & 0.000041 & 1.15133 & 0.000012 \\
\hline 17.3 & 37.70398 & 0.00386 & 15.58717 & 0.00169 & 17.8752 & 0.00188 & 2.10931 & 0.000042 & 1.14679 & 0.000016 \\
\hline 19.1 & 37.99162 & 0.00214 & 15.59977 & 0.00073 & 18.02459 & 0.00082 & 2.10773 & 0.000041 & 1.15546 & 0.00001 \\
\hline 22.7 & 38.22536 & 0.00204 & 15.61534 & 0.00079 & 18.23794 & 0.00091 & 2.09592 & 0.000041 & 1.16796 & 0.000013 \\
\hline 23.6 & 38.19245 & 0.00151 & 15.61474 & 0.00057 & 18.20114 & 0.00069 & 2.09841 & 0.000047 & 1.16564 & 0.000012 \\
\hline 25.6 & 38.28559 & 0.00206 & 15.61802 & 0.00079 & 18.30171 & 0.00085 & 2.09192 & 0.000037 & 1.17183 & 0.000011 \\
\hline 28.6 & 38.34574 & 0.00216 & 15.6209 & 0.00084 & 18.36624 & 0.00093 & 2.08791 & 0.000046 & 1.17571 & 0.000014 \\
\hline 30.6 & 38.35816 & 0.00193 & 15.61779 & 0.00084 & 18.38396 & 0.00099 & 2.08651 & 0.000039 & 1.17711 & 0.000012 \\
\hline 40.6 & 38.37774 & 0.0023 & 15.62146 & 0.0008 & 18.39727 & 0.00084 & 2.08609 & 0.000041 & 1.17768 & 0.000012 \\
\hline
\end{tabular}

can be assessed using reference lithogenic elements conservative during mineral weathering and without substantial anthropogenic sources. We determined enrichment factors (EF) as follows (Shotyk et al., 2000):

$\mathrm{EF}=([\mathrm{M}] /[\mathrm{X}])_{\text {Peat }} /([\mathrm{M}] /[\mathrm{X}])_{\text {Local }}$

where $[\mathrm{M}]_{\text {Peat }}$ is the total concentration of the element measured in the peat sample,

$[\mathrm{X}]_{\text {Peat }}$ is the total concentration of the conservative element measured in the sample,

([M], $[\mathrm{X}])_{\text {local }}$ is the abundance measured at the bottom section of the bog, by averaging the value of 45 samples taken from 600 to $750 \mathrm{~cm}$, representing the natural pre-anthropic elemental background (Allan, unpublished data).

\subsection{Statistical analysis}

Multivariate statistical techniques can help to simplify and organize large data sets to provide significant insight (Laaksoharju et al., 1999). In the present study, Hierarchical cluster analysis was used to evaluate the rate accumulation of trace elements in core $01 \mathrm{~W}$. The objects are grouped such that similar objects fall into the same class. Hierarchical clustering joins the most similar observations, and then successively the next most similar observations. The levels of similarity at which observations are merged are used to construct a dendrogram.

\section{Results}

\subsection{Element geochemistry profiles}

In core $01 \mathrm{~W}, \mathrm{Al}, \mathrm{Sc}$ and $\mathrm{Ti}$ concentrations display generally similar variations (Fig. 2). In the uppermost $18 \mathrm{~cm}$ (from AD 1970 to 2008 ) the concentrations decline for all three elements to $156,0.11$ and $113 \mu \mathrm{g} \mathrm{g}^{-1}$, respectively. This sharp decrease coincides with a decrease, by a factor 10 , of the peat density. Aluminum and $\mathrm{Ti}$ concentrations measured in core $06 \mathrm{~W}$, also display generally similar variations (Fig. 2). The upper part of the core is characterized by living and/or poorly decomposed Sphagnum, where the acrotelm/catotelm boundary is located at $\sim 17 \mathrm{~cm}$ for core $01 \mathrm{~W}$ (AD 1977) and at $8 \mathrm{~cm}$ for core 06W (AD 1990).

Dry bulk density ranges from 0.01 to $0.2 \mathrm{~g} \mathrm{~cm}^{-3}$. These values vary between 0.08 and 0.18 from the lower part of the cores up to 25-15 cm (from AD 1800 to 1990), and then they decrease to the peat surface. In $06 \mathrm{~W}, \mathrm{Al}$ and $\mathrm{Ti}$ concentrations are similar to those in 01W, except between 8 and $17 \mathrm{~cm}$ depth (from AD 1880 to 1990) where $\mathrm{Al}$ and $\mathrm{Ti}$ show a clear peak. We suggest that the higher $\mathrm{Al}$ and $\mathrm{Ti}$ concentrations found in the $06 \mathrm{~W}$ hummock-hollow core are due to an increase in input of mineral matter coming from various anthropic sources (e.g. land clearance, intensive agriculture and mining activities).

In $01 \mathrm{~W}, \mathrm{~V}, \mathrm{Cr}$ and $\mathrm{Co}$ values remain stable between 38 and $30 \mathrm{~cm}$ (from AD 1420 to 1690), and then their concentrations increase and reach a maximum of 22,31 and $2.2 \mu \mathrm{g} \mathrm{g}^{-1}$ (respectively) at $19 \mathrm{~cm}$ (AD 1953-1973). The concentrations decrease sharply and then remain almost stable until the surface. In $06 \mathrm{~W}, \mathrm{~V}$ and $\mathrm{Cr}$ values remain stable from 38 to $18 \mathrm{~cm}$, and then they increase and reach a maximum of 26 and $56 \mu \mathrm{g} \mathrm{g}^{-1}$ (respectively) at $10 \mathrm{~cm}$ (AD 19751985). In both cores, Ni values increase by a factor of 2 between 40 and $22 \mathrm{~cm}$ (from AD 1420 to 1880), and the maximum concentrations of (11 and $14 \mu \mathrm{g} \mathrm{g}^{-1}$, respectively) are reached at 17 and $10 \mathrm{~cm}$ (respectively).

There is no variation in the vertical distribution of $\mathrm{Cu}$ $\left(\sim 2 \mu \mathrm{g} \mathrm{g}^{-1}\right.$ ) from 40 to $29 \mathrm{~cm}$ (between AD 1420 and 1690) in both cores. Copper values increase from $29 \mathrm{~cm}$ (AD 1690) toward the surface; with a maximum at $18 \mathrm{~cm}$ for $01 \mathrm{~W}\left(38 \mu \mathrm{g} \mathrm{g}^{-1}\right.$ at AD 1971) and for $06 \mathrm{~W}$ at $14 \mathrm{~cm}\left(40 \mu \mathrm{g} \mathrm{g}^{-1}\right.$ at $\mathrm{AD}$ 1937). Arsenic and $\mathrm{Pb}$ concentrations in $01 \mathrm{~W}$ strongly increase from $40 \mathrm{~cm}$ (AD 1420) and reach their maxima ( $>8$ and $660 \mu \mathrm{g} \mathrm{g}^{-1}$, respectively) between 23 and $16 \mathrm{~cm}$ (from AD 1880 to 1965). In core 06W, Pb values increase and reach a maximum $>930 \mu \mathrm{g} \mathrm{g}^{-1}$ at $14 \mathrm{~cm}$ (AD 1937). Cadmium and $\mathrm{Zn}$ concentrations strongly increase between 40 and $30 \mathrm{~cm}$ (13 and $300 \mu \mathrm{g} \mathrm{g}^{-1}$, respectively) and then decrease toward the surface, with two large peaks at $29 \mathrm{~cm}$ (AD 169) and at $12 \mathrm{~cm}$ (AD 1996). The $\mathrm{Sb}$ values remain stable between 40 and $30 \mathrm{~cm}$ (from AD 1420 to 169), but thereafter increase and reach a maximum $>9 \mu \mathrm{g} \mathrm{g}^{-1}$ between 23 and $16 \mathrm{~cm}$ (from AD 1880 to 1965 ).

To summarize, $\mathrm{V}, \mathrm{Cr}, \mathrm{Ni}, \mathrm{Cu}, \mathrm{Zn}$, and $\mathrm{Pb}$ display generally similar profiles in both cores $01 \mathrm{~W}$ and $06 \mathrm{~W}$. These trace metals record their maximum values between 22 and $12 \mathrm{~cm}$ for core $01 \mathrm{~W}$ (from AD 1880 to 1996) and between 14 and $7 \mathrm{~cm}$ for core 06W (from AD 1937 to 1995$)$.

\subsection{Enrichment factor}

Enrichments of trace metals beyond those expected only by changes in the supply of mineral matter are mainly related to

Table 3

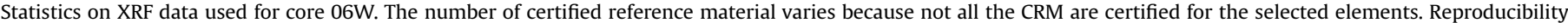
values are the median values of 10 measurements performed on 3 certified reference materials: NIMT-UOE-FM-001, NJV-94-2 and NIST-1515.

\begin{tabular}{|c|c|c|c|c|c|c|c|c|c|c|c|c|c|c|c|c|c|c|c|c|}
\hline & $\mathrm{Na}$ & $\mathrm{Mg}$ & $\mathrm{K}$ & $\mathrm{Ca}$ & $\mathrm{Al}$ & $\mathrm{Si}$ & $\mathrm{Ti}$ & $\mathrm{Fe}$ & Mn & $\mathrm{Ba}$ & $\mathrm{Rb}$ & $\mathrm{Sr}$ & $S$ & $\mathrm{P}$ & $\mathrm{Cl}$ & $\mathrm{Br}$ & $\mathrm{Cu}$ & $\mathrm{Zn}$ & $\mathrm{Pb}$ & $\mathrm{Ni}$ \\
\hline $\mathrm{Nr}$ of CRM & 13 & 16 & 19 & 19 & 17 & 8 & 8 & 16 & 22 & 5 & 10 & 12 & 10 & 10 & 12 & 7 & 23 & 24 & 9 & 12 \\
\hline $\operatorname{LLD}\left(\mu \mathrm{g} \mathrm{g}^{-1}\right)$ & 20 & 16 & 7 & 6 & 3 & 16 & 2 & 9 & 1 & 54 & 1 & 1 & 8 & 10 & 7 & 2 & 0.4 & 0.5 & 2 & 0.5 \\
\hline Accuracy (\%) & 8 & 6 & 7 & 5 & 9 & 19 & 11 & 12 & 4 & 4 & 11 & 17 & 10 & 6 & 6 & 7 & 10 & 8 & 12 & 9 \\
\hline Reproducibility (\%) & 78 & 98 & 97 & 99 & 98 & 95 & 98 & 97 & 97 & 53 & 93 & 98 & 99 & 97 & 99 & 92 & 88 & 98 & 92 & 77 \\
\hline
\end{tabular}



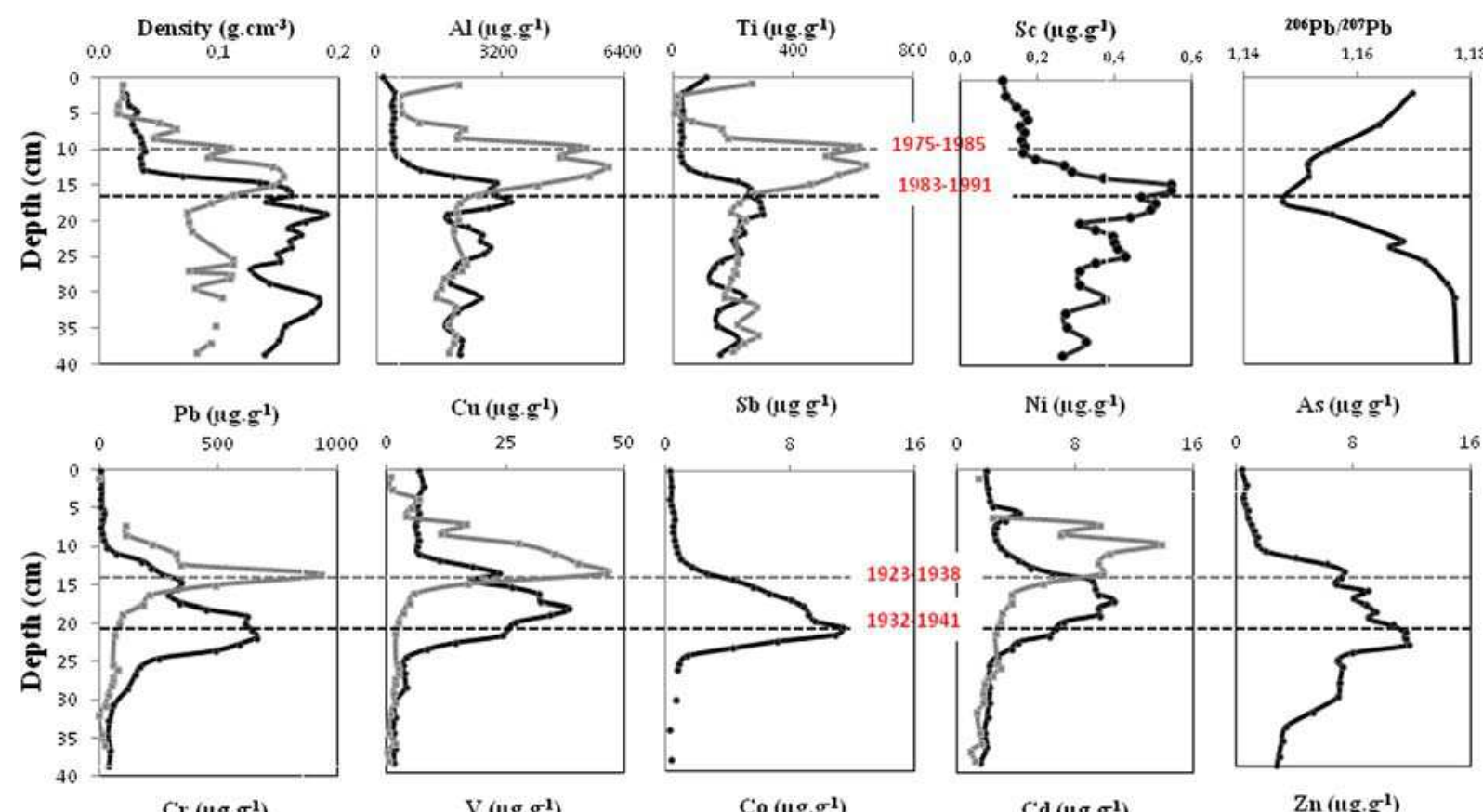

As $\left(\mu g g^{1}\right)$
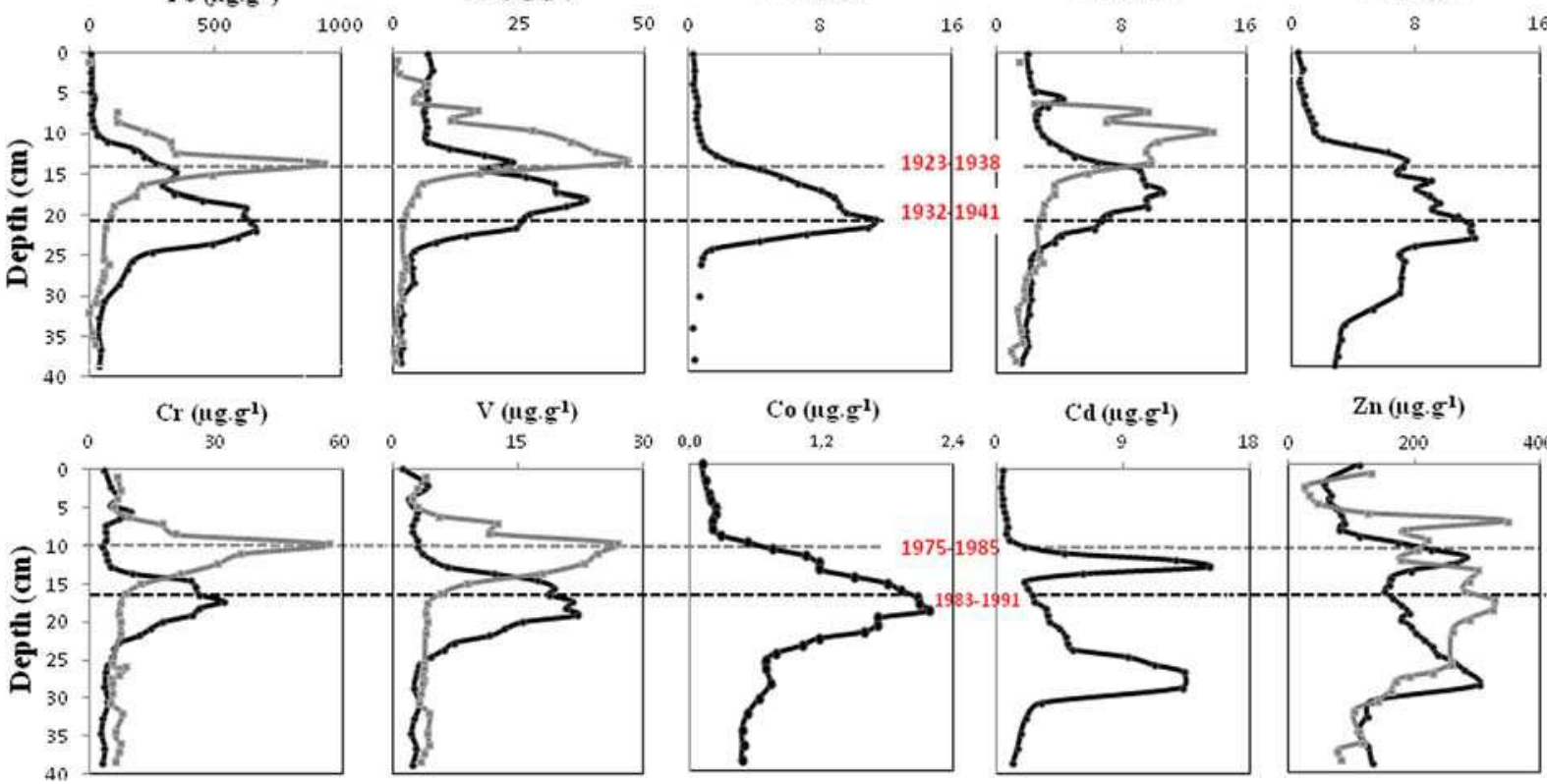

Fig. 2. Major and trace element concentration $\left(\mu \mathrm{g} \mathrm{g}^{-1}\right.$ ) and $\mathrm{Pb}$ isotope ratios versus depth in both $01 \mathrm{~W}$ (black line) and $06 \mathrm{~W}$ (gray line) cores.

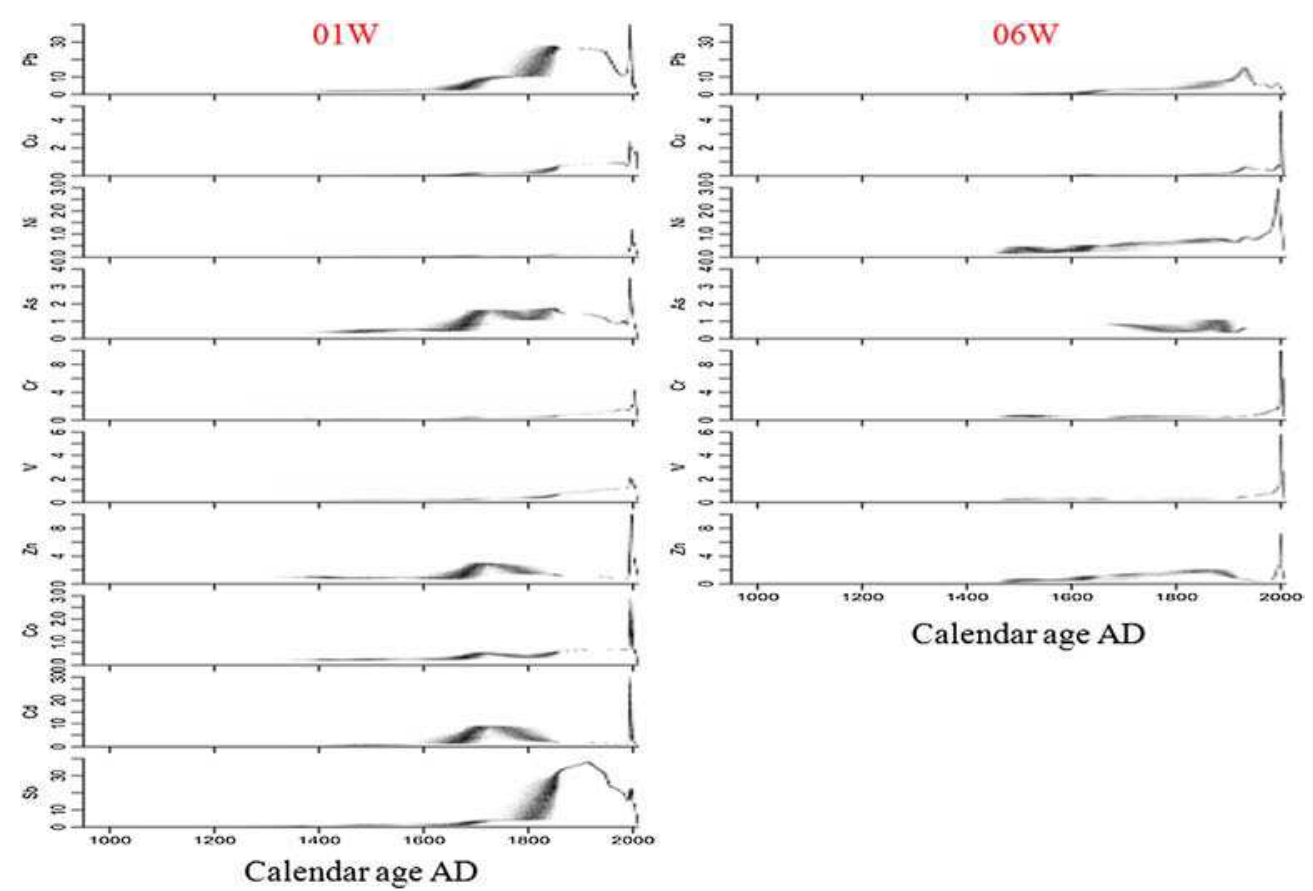

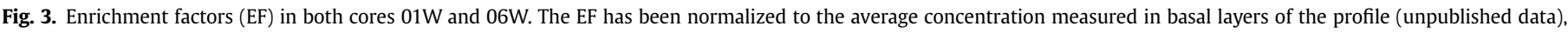
using $\mathrm{Ti}$ as reference element. 

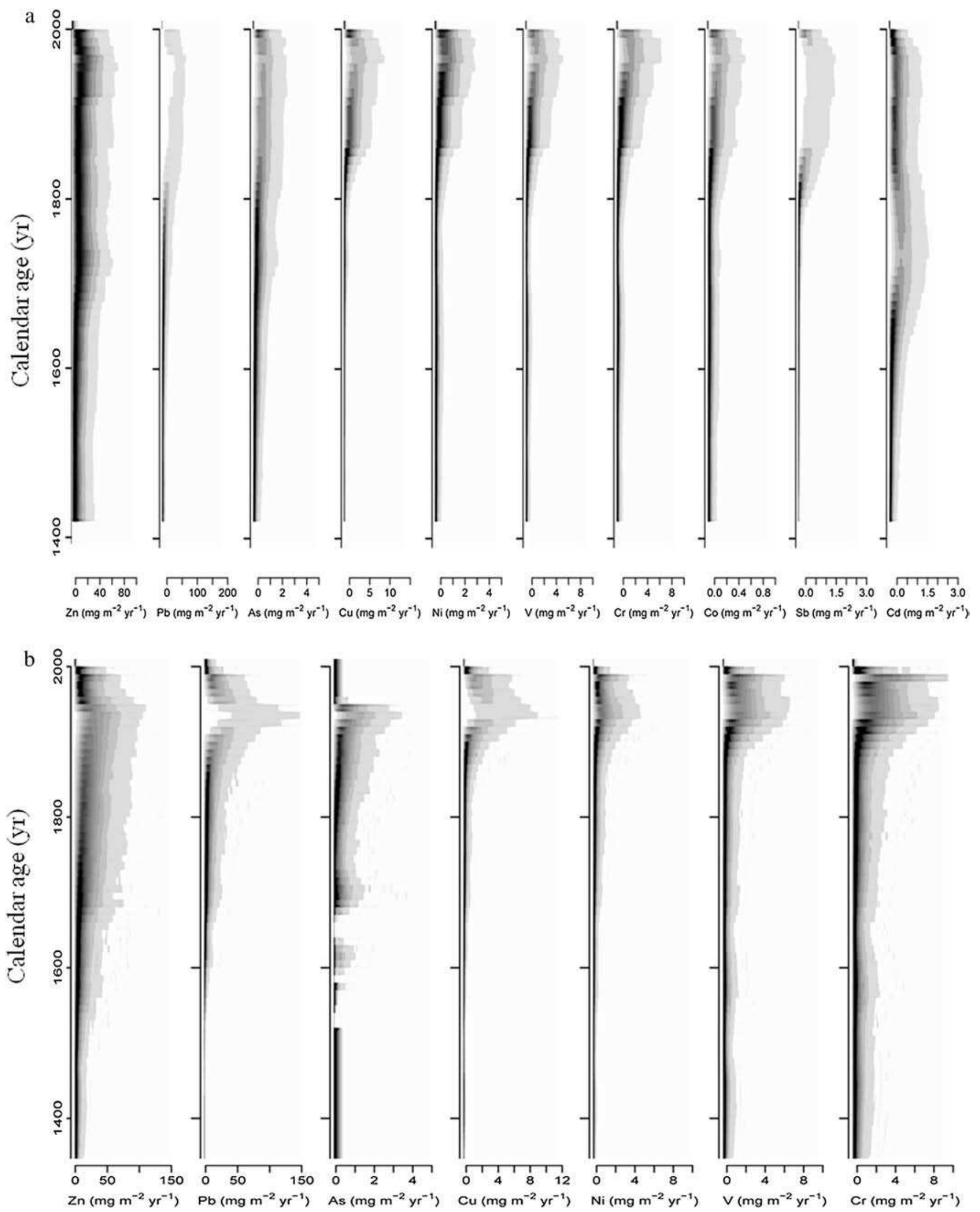

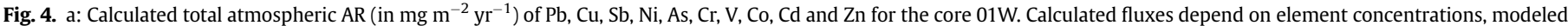

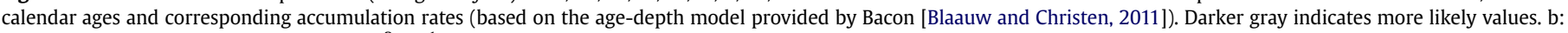
Calculated total atmospheric AR (in $\mathrm{mg} \mathrm{m}^{-2} \mathrm{yr}^{-1}$ ) of $\mathrm{Pb}, \mathrm{Cu}, \mathrm{Ni}, \mathrm{As}, \mathrm{Cr}, \mathrm{V}$ and $\mathrm{Zn}$ for the core $06 \mathrm{~W}$. 
anthropogenic-derived contributions. In the Misten bog records (Fig. 3), EF are the most pronounced for $\mathrm{Pb}$ and $\mathrm{Sb}$ with maximum EF values $>40$, followed by Cd ( $>30$ ). Copper, Ni, V, Co, Cr, Zn, and As are characterized by EF values averaging $\sim 2-3$ times the background values at the base of the peat sequence. Then EF values increase and reach a maximum between AD 1930 and 2000. In both cores, $\mathrm{EF}$ values of all trace metals (except $\mathrm{Cd}$ and $\mathrm{Zn}$ ) remain stable from $A D 1400$ to 1700 . The relative increase in $E F$ is not the same for the metals from AD 1700 to 2000 . $\mathrm{EF}_{\mathrm{Pb}}$ increases by a factor of $10-$ 20 (2.5-50 for $01 \mathrm{~W}, 2.6$ to 20 for $06 \mathrm{~W})$. $\mathrm{EF}_{\mathrm{Cu}}$ increases by a factor of $50-70(0.05-2.5$ for $01 \mathrm{~W}, 0.07$ to 4.5 for $06 \mathrm{~W})$. $\mathrm{EF}_{\mathrm{Sb}}$ in core $01 \mathrm{~W}$ increases by a factor of 20, from 1 at 1700 to $22-40$ at AD 19301991. $\mathrm{EF}_{\mathrm{Ni}}$ increases by a factor of $5-30$, from 0.04 to 1.2 for $01 \mathrm{~W}$ and from 0.06 to 0.3 for $06 \mathrm{~W}$. $\mathrm{EF}_{\mathrm{As}}$ increases by a factor of 10 , from 0.4 to 3.5 (between $\mathrm{AD} 1700$ and 1983-1991). $\mathrm{EF}_{\mathrm{Cr}}$ increases by a factor of $10-30$ between $A D 1700$ and 2000 in both cores. $\mathrm{EF}_{\mathrm{Co}}$ increases by a factor $>100$ between AD 1700 and 1995 in the core $01 \mathrm{~W}$. $\mathrm{EF}_{\mathrm{V}}$ increases by a factor of $10-20$, from 0.2 to 2.2 for $01 \mathrm{~W}$ and from 0.3 to 6 for $06 \mathrm{~W} . \mathrm{EF}_{\mathrm{Zn}}$ increases by a factor of 5-15 from ca. AD 1700 to 2000 . $\mathrm{EF}_{\mathrm{Cd}}$ increases by a factor of 30 from ca. AD 1700 to 2000 in core $01 \mathrm{~W}$. All EF values decrease toward the surface.

\subsection{Lead isotope ratios}

Table 2 summarizes results of $\mathrm{Pb}$ isotope analyses. In core $01 \mathrm{~W}$ (Table 2), ${ }^{208} \mathrm{~Pb} /{ }^{204} \mathrm{~Pb},{ }^{207} \mathrm{~Pb} /{ }^{204} \mathrm{~Pb}$ and ${ }^{206} \mathrm{~Pb} /{ }^{204} \mathrm{~Pb}$ isotopic ratios decrease from $40.6 \mathrm{~cm}$ (respectively, $38.3777 \pm 0.0023$, $15.6215 \pm 0.0008$ and $18.3973 \pm 0.0008$ ) to $17.3 \mathrm{~cm}$ (respectively, $37.7039 \pm 0.0039,15.5872 \pm 0.0017$ and $17.8752 \pm 0.0019$ ). From $13.7 \mathrm{~cm}$ to the surface of bog, the values of $\mathrm{Pb}$ isotope ratios show an increase (respectively, between $37.8952 \pm 0.0022$ and $38.0051 \pm$ 0.0025 , between $15.59218 \pm 0.0009$ and $15.6364 \pm 0.0009$ and between $17.9533 \pm 0.0011$ and $18.29126 \pm 0.001)$.

\subsection{Trace metals accumulation rates}

In order to examine the historical record of pollution, we calculated the total accumulation rate (AR) of the trace metals in both cores (Fig. 4). Pre-anthropogenic AR for the trace metals were measured in the deepest peat layers (from 600 to $750 \mathrm{~cm}, n=45$ ) $\left(\mathrm{Pb} \mathrm{AR}=0.15 \mathrm{mg} \mathrm{m}^{-2} \mathrm{yr}^{-1}, \mathrm{Cu} \mathrm{AR}=0.18 \mathrm{mg} \mathrm{m}^{-2} \mathrm{yr}^{-1}, \mathrm{Sb} \mathrm{AR}=\right.$ $0.003 \mathrm{mg} \mathrm{m}^{-2} \mathrm{yr}^{-1}$, Ni AR $=0.22 \mathrm{mg} \mathrm{m}^{-2} \mathrm{yr}^{-1}$, As AR $=$ $0.002 \mathrm{mg} \mathrm{m}^{-2} \mathrm{yr}^{-1}, \mathrm{Cr}$ AR $=0.12 \mathrm{mg} \mathrm{m}^{-2} \mathrm{yr}^{-1}, \mathrm{~V} \mathrm{AR}=$ $0.06 \mathrm{mg} \mathrm{m} \mathrm{m}^{-2} \mathrm{yr}^{-1}$, Co AR $=0.11 \mathrm{mg} \mathrm{m}^{-2} \mathrm{yr}^{-1}$, Cd AR = $0.02 \mathrm{mg} \mathrm{m}^{-2} \mathrm{yr}^{-1}$, and $\left.\mathrm{Zn} \mathrm{AR}=2 \mathrm{mg} \mathrm{m}^{-2} \mathrm{yr}^{-1}\right)$. They are by far lower than the accumulation rates in the recent peat layers.

The $\mathrm{Pb}$ AR remained lower than $2 \mathrm{mg} \mathrm{m}^{-2} \mathrm{yr}^{-1}$ before the 17th century. The $\mathrm{Pb}$ AR increases from AD 1690 up to a maximum $>100 \mathrm{mg} \mathrm{m}^{-2} \mathrm{yr}^{-1}$ at AD 1937 for 06W and at AD 1990 for $01 \mathrm{~W}$. Since then the $\mathrm{Pb}$ AR has decreased to 4 and $0.2 \mathrm{mg} \mathrm{m}^{-2} \mathrm{yr}^{-1}$ (respectively) at the surface in both cores (01W and 06W).

The AR of $\mathrm{V}, \mathrm{Cr}, \mathrm{Co}, \mathrm{Ni}, \mathrm{Cu}, \mathrm{As}$ and $\mathrm{Sb}$ remained stable and lower in the lower part of the core between AD 1350 and 1690 (from 40 to $30 \mathrm{~cm}$ ). The maximum AR is observed between AD 1930 and 1995 for all trace metals (Fig. 4). The relative increase in accumulation rates is not the same for the metals for the period (AD 1750 to $A D$ 1980-1990):

- Copper AR increases by a factor of 15-50 (0.3-7 $\mathrm{mg} \mathrm{m}^{-2} \mathrm{yr}^{-1}$ for 01W, 0.1-3 for 06W) between AD 1750 and 1980-1990;

- Antimony AR in core $01 \mathrm{~W}$ increases by a factor of 50 , from $0.04 \mathrm{mg} \mathrm{m}^{-2} \mathrm{yr}^{-1}$ at 1750 to $\sim 2 \mathrm{mg} \mathrm{m}^{-2} \mathrm{yr}^{-1}$ at $\mathrm{AD} 1983-$ 1991;

- Nickel AR increases by a factor of 25-50, from 0.08 to $3 \mathrm{mg} \mathrm{m}^{-2} \mathrm{yr}^{-1}$ for both cores, during the same time interval;

- Arsenic AR increases by a factor of 5, from 0.5 to $2.5 \mathrm{mg} \mathrm{m}^{-2} \mathrm{yr}^{-1}$ (between AD 1750 and 1983-1991);

- Chromium AR increases by a factor of 25-30 between AD 1750 and 1980-1990 in both cores;

- Cobalt AR increases by a factor of 25-30 between AD 1750 and 1980-1990 in the core 01W;

- Vanadium AR increases by a factor of 25-30, from 0.1 to $6 \mathrm{mg} \mathrm{m}^{-2} \mathrm{yr}^{-1}$ for both cores, during the same time interval;

- Zinc AR increases by a factor of 5-50 from ca. AD 1750 to 1995 in both cores;

- Cadmium AR increases by a factor of 5-50 from ca. AD 1750 to 1995 in core $01 \mathrm{~W}$.

\subsection{Cumulative inventories of trace metals}

We also investigated the variability of the total cumulative inventories of different trace elements (Table 3 ) considering the two peat cores and the depth until no unsupported ${ }^{210} \mathrm{~Pb}$ can be detected (Le Roux et al., 2005). The ${ }^{210} \mathrm{~Pb}$ inventories of the two cores, respectively $6.7 \mathrm{kBq} \mathrm{m}^{-2}$ for $01 \mathrm{~W}$ and $4.3 \mathrm{kBq} \mathrm{m}^{-2}$ for $06 \mathrm{~W}$ (De Vleeschouwer et al., 2010a), are in agreement with what can be expected (Le Roux and Marshall, 2011) considering the average annual rainfall in this area $(\sim 1400 \mathrm{~mm})$. The higher inventory $(56 \%$ higher) for ${ }^{210} \mathrm{~Pb}$ in the hummock core $(01 \mathrm{~W})$ as compared to the hummock-hollow transition core $(06 \mathrm{~W})$ was also found for $\mathrm{Pb}$ (70\%), $\mathrm{Cu}(26 \%), \mathrm{V}$ (33\%), and $\mathrm{Ni}$ (34\%) and to a lesser extent for $\mathrm{Cr}$ (16\%) and $\mathrm{Zn}(7 \%)$. In contrast to the trace metals, lithogenic elements $(\mathrm{Al}, \mathrm{Ti})$ have lower inventories in $01 \mathrm{~W}$ than in $06 \mathrm{~W}$. In order to understand these discrepancies, we also calculated the inventories of pollen grains from a palynological investigation on the same two cores (De Vleeschouwer et al., 2010c). Table 4 shows both the inventories of major pollen types as well as the typical average size of the pollen grains. The pollen grains have a larger size than the average atmospheric particles transporting trace metals (Allen et al., 2001; Baeyens and Dedeeurwaerder, 1991; Injuk et al., 1992), which are mainly transported by submicronic aerosols. A large part of lithogenic elements are deposited as large atmospheric particles derived from local transport. The pollen inventories show that there is a good agreement between the two cores, except for Pinus and Quercus pollen, which is known to be long-range transported and thus possibly affected by atmospheric processes similar to submicronic aerosols (Allen et al., 2001). Bog pollen grains such as of Betula also show good agreement. The differences between the

Table 4

Cumulative inventories of ${ }^{210} \mathrm{~Pb}, \mathrm{~Pb}, \mathrm{Zn}, \mathrm{Cu}, \mathrm{V}, \mathrm{Ni}, \mathrm{Cr}, \mathrm{Al}$, and Ti for Misten peat cores (01W and 06W).

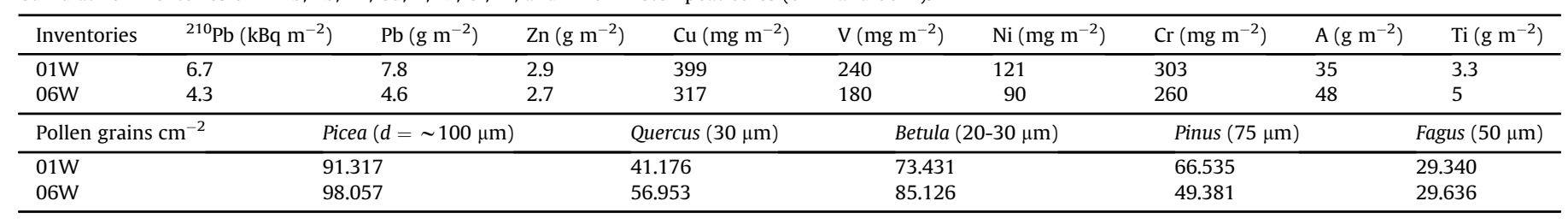


lithogenic elements ( $\mathrm{Al}, \mathrm{Ti})$ tracing large particles, trace elements carried by submicronic particles and pollen rain can be explained by different processes at the air-peat ground interface. At Misten bog, in a large open area, the differences can be mainly explained by differences in microtopography, affecting movements of particles and snow during winter. These movements are more susceptible to affect long-range transport particles emitted all year around or even more in winter due to domestic fuel consumption than pollen grains or large particles emitted during spring and summer. The minor remaining discrepancies in the cumulative inventories values of different trace elements between $01 \mathrm{~W}$ and $06 \mathrm{~W}$ are explained by the position of the coring itself. $01 \mathrm{~W}$ core was taken on a hummock, while 06W core was taken between a hummock and a hollow (to record a maximum of wetness changes, according to De Vleeschouwer et al., 2010a,b; Aaby, 1976).

\section{Discussion}

\subsection{Trace metal and metalloid mobility}

One aim of this study was to assess the possible postdepositional mobility of trace metals in peat cores before interpreting the accumulation rates as quantitative records of past atmospheric deposition. This is especially critical when dealing with high-resolution records of fresh, poorly decomposed peat accumulating in the acrotelm.

In both the $01 \mathrm{~W}$ and $06 \mathrm{~W}$ cores, we suggest that most of the trace metals $(\mathrm{V}, \mathrm{Cr}, \mathrm{Co}, \mathrm{Ni}, \mathrm{Cu}, \mathrm{As}, \mathrm{Pb}$ and $\mathrm{Sb})$ are largely immobile in the upper part of the Misten bog for two reasons. First, the timing of the maximum concentration and accumulation rate of $\mathrm{Pb}$ is consistent between the two cores from different settings on the bog and with that in other European peat bogs (e.g., Shotyk et al., 1996, 1998, 2002; Cloy et al., 2005; Olid et al., 2010), and with records based on herbarium collections (Bacon et al., 1996; Weiss et al., 1999; Farmer et al., 2002) and lake sediments (e.g. Renberg et al., 2001). Moreover, in the Misten bog record there is a consistency among the concentration profiles of $\mathrm{Cu}, \mathrm{V}, \mathrm{Ni}$ and $\mathrm{Cr}$ and that for $\mathrm{Pb}$ (Fig. 2, 3; Table 5). Lead positively correlated with all metals studied along the both cores (Table 5).

Second, preservation of the atmospheric record is indicated by the comparison between $\mathrm{V}, \mathrm{Cr}, \mathrm{Ni}, \mathrm{Cu}$ and $\mathrm{Pb}$ concentrations in $01 \mathrm{~W}$ and $06 \mathrm{~W}$ cores (Fig. 2). This comparison shows that maximum concentrations are between 18 and $22 \mathrm{~cm}$-depth for $01 \mathrm{~W}$ and between 10 and $14 \mathrm{~cm}$-depth for $06 \mathrm{~W}$, but the change in their concentrations are similar in time (Fig. 2). This difference in concentration values between $01 \mathrm{~W}$ and $06 \mathrm{~W}$ are explained by the position of the coring itself. $01 \mathrm{~W}$ core was taken on a hummock, while $06 \mathrm{~W}$ core was taken between a hummock and a hollow, where hummocks are known to have higher interception of trace metals (Damman, 1978; Oldfield et al., 1995; Norton et al., 1998) (see discussion below). The similar chronologies of some trace metals profiles in $01 \mathrm{~W}$ and $06 \mathrm{~W}$ peat sites with different characteristics and with different peat accumulation rates suggest that these records are preserved in the Misten bog deposit.

\subsection{Trace metal sources}

\subsection{1. $\mathrm{Pb}$ isotope}

Lead isotope ratios of peat samples allow the identification of the natural and anthropogenic sources of $\mathrm{Pb}$, because many sources of $\mathrm{Pb}$ are characterized by different isotope ratios (e.g., Shirahata et al., 1980). In the binary diagram ${ }^{208} \mathrm{~Pb} /{ }^{206} \mathrm{~Pb} v s .{ }^{206} \mathrm{~Pb} /{ }^{207} \mathrm{~Pb}$, most of the $01 \mathrm{~W}$ core data plot between the isotope field defined by Belgian ores, Belgian Zn-smelter, and Benelux urban aerosols measured during the leaded gasoline era (Fig. 5a). Eifel ores (DuraliMueller et al., 2007), Belgian Pb-Zn ores (Cauet and Herbosh, 1982; Dejonghe, 1998) Benelux and Germany aerosol (Bollhöfer and Rosman, 2001) define a mixing line on which many of the samples lie. Lead isotope ratios measured in samples dated between $A D$ 1690 and 1953 correspond to the isotopic fields of the $\mathrm{Pb}-\mathrm{Zn}$ ores of the Verviers syncline and the Eifel ores (Durali-Mueller et al., 2007). The sample located in the upper part of the core (AD 1969-1977) has isotope ratios nearest to the values of the Belgian Zn-smelter (Sonk et al., 2002) and Benelux aerosols (Bollhöfer and Rosman, 2001). Our results are consistent with those obtained by De Vleeschouwer et al. (2007) in a former core recovered in the Misten bog (Fig. 5a).

The recent samples (from AD 1994 to 2007) do not lie on the mixing line between the two identified potential sources (i.e. Belgian ores and Benelux aerosols; Fig. 5a). Their ${ }^{206} \mathrm{~Pb} /{ }^{207} \mathrm{~Pb}$ ratios, which vary from 1.147 to 1.169 , are aligned along a second linear trend. This second trend was previously mentioned by Véron et al.

Table 5

Pearson correlation coefficients between metal concentrations in both cores, significant correlations in bold ( $r$ value).

\begin{tabular}{|c|c|c|c|c|c|c|c|c|c|c|c|c|c|}
\hline Core $01 \mathrm{~W}$ & $\mathrm{Al}$ & Sc & $\mathrm{Ti}$ & V & $\mathrm{Cr}$ & Co & $\mathrm{Ni}$ & $\mathrm{Cu}$ & $\mathrm{Zn}$ & As & $\mathrm{Cd}$ & $\mathrm{Sb}$ & $\mathrm{Pb}$ \\
\hline $\mathrm{Al}$ & 1 & 0.92 & 0.90 & 0.61 & 0.56 & 0.69 & 0.53 & 0.45 & 0.41 & 0.77 & 0.20 & 0.57 & 0.62 \\
\hline Sc & 0.92 & 1 & 0.86 & 0.79 & 0.73 & 0.83 & 0.73 & 0.63 & 0.42 & 0.78 & 0.22 & 0.64 & 0.68 \\
\hline $\mathrm{Ti}$ & 0.90 & 0.86 & 1 & 0.71 & 0.66 & 0.76 & 0.61 & 0.58 & 0.29 & 0.73 & 0.05 & 0.70 & 0.70 \\
\hline V & 0.61 & 0.79 & 0.71 & 1 & 0.96 & 0.95 & 0.98 & 0.95 & 0.20 & 0.67 & -0.02 & 0.84 & 0.75 \\
\hline $\mathrm{Cr}$ & 0.56 & 0.73 & 0.66 & 0.96 & 1 & 0.86 & 0.97 & 0.89 & 0.06 & 0.55 & -0.13 & 0.76 & 0.61 \\
\hline Co & 0.69 & 0.83 & 0.76 & 0.95 & 0.86 & 1 & 0.91 & 0.92 & 0.44 & 0.81 & 0.21 & 0.88 & 0.85 \\
\hline $\mathrm{Ni}$ & 0.53 & 0.73 & 0.61 & 0.98 & 0.97 & 0.91 & 1 & 0.95 & 0.19 & 0.63 & -0.01 & 0.81 & 0.70 \\
\hline $\mathrm{Cu}$ & 0.45 & 0.63 & 0.58 & 0.95 & 0.89 & 0.92 & 0.95 & 1 & 0.20 & 0.65 & 0.02 & 0.87 & 0.76 \\
\hline $\mathrm{Zn}$ & 0.41 & 0.42 & 0.29 & 0.20 & 0.06 & 0.44 & 0.19 & 0.20 & 1 & 0.66 & 0.90 & 0.26 & 0.47 \\
\hline As & 0.77 & 0.78 & 0.73 & 0.67 & 0.55 & 0.81 & 0.63 & 0.65 & 0.66 & 1 & 0.45 & 0.81 & 0.92 \\
\hline $\mathrm{Cd}$ & 0.20 & 0.22 & 0.05 & -0.02 & -0.13 & 0.21 & -0.01 & 0.02 & 0.90 & 0.45 & 1 & 0.02 & 0.23 \\
\hline $\mathrm{Sb}$ & 0.57 & 0.64 & 0.70 & 0.84 & 0.76 & 0.88 & 0.81 & 0.87 & 0.26 & 0.81 & 0.02 & 1 & 0.94 \\
\hline $\mathrm{Pb}$ & 0.62 & 0.68 & 0.70 & 0.75 & 0.61 & 0.85 & 0.70 & 0.76 & 0.47 & 0.92 & 0.23 & 0.94 & 1 \\
\hline Core 06W & \multicolumn{2}{|r|}{$\mathrm{Ti}$} & \multicolumn{2}{|c|}{$\mathrm{Al}$} & $\mathrm{Cu}$ & \multicolumn{2}{|c|}{$\mathrm{Zn}$} & V & \multicolumn{2}{|r|}{$\mathrm{Cr}$} & \multicolumn{2}{|l|}{$\mathrm{Pb}$} & $\mathrm{Ni}$ \\
\hline $\mathrm{Ti}$ & \multicolumn{2}{|r|}{1} & \multicolumn{2}{|c|}{0.94} & 0.81 & \multicolumn{2}{|c|}{0.40} & 0.83 & \multicolumn{2}{|r|}{0.75} & \multicolumn{2}{|l|}{0.71} & 0.77 \\
\hline $\mathrm{Al}$ & \multicolumn{2}{|r|}{0.94} & \multicolumn{2}{|c|}{1} & 0.88 & \multicolumn{2}{|c|}{0.46} & 0.87 & \multicolumn{2}{|r|}{0.77} & \multicolumn{2}{|l|}{0.78} & 0.84 \\
\hline $\mathrm{Cu}$ & \multicolumn{2}{|r|}{0.81} & \multicolumn{2}{|c|}{0.88} & 1 & \multicolumn{2}{|c|}{0.25} & 0.91 & \multicolumn{2}{|r|}{0.78} & \multicolumn{2}{|l|}{0.83} & 0.88 \\
\hline $\mathrm{Zn}$ & \multicolumn{2}{|r|}{0.40} & \multicolumn{2}{|c|}{0.46} & 0.25 & \multicolumn{2}{|c|}{1} & 0.23 & \multicolumn{2}{|r|}{0.16} & \multicolumn{2}{|l|}{0.44} & 0.41 \\
\hline V & \multicolumn{2}{|r|}{0.83} & \multicolumn{2}{|c|}{0.87} & 0.91 & \multicolumn{2}{|c|}{0.23} & 1 & \multicolumn{2}{|r|}{0.95} & 0.61 & & 0.95 \\
\hline $\mathrm{Cr}$ & & 0.75 & & & 0.78 & & & 0.95 & & 1 & 0.45 & & 0.92 \\
\hline $\mathrm{Pb}$ & & 0.71 & & & 0.83 & & & 0.61 & & 0.45 & 1 & & 0.65 \\
\hline $\mathrm{Ni}$ & & 0.77 & & & 0.88 & & & 0.95 & & 0.92 & 0.65 & & 1 \\
\hline
\end{tabular}



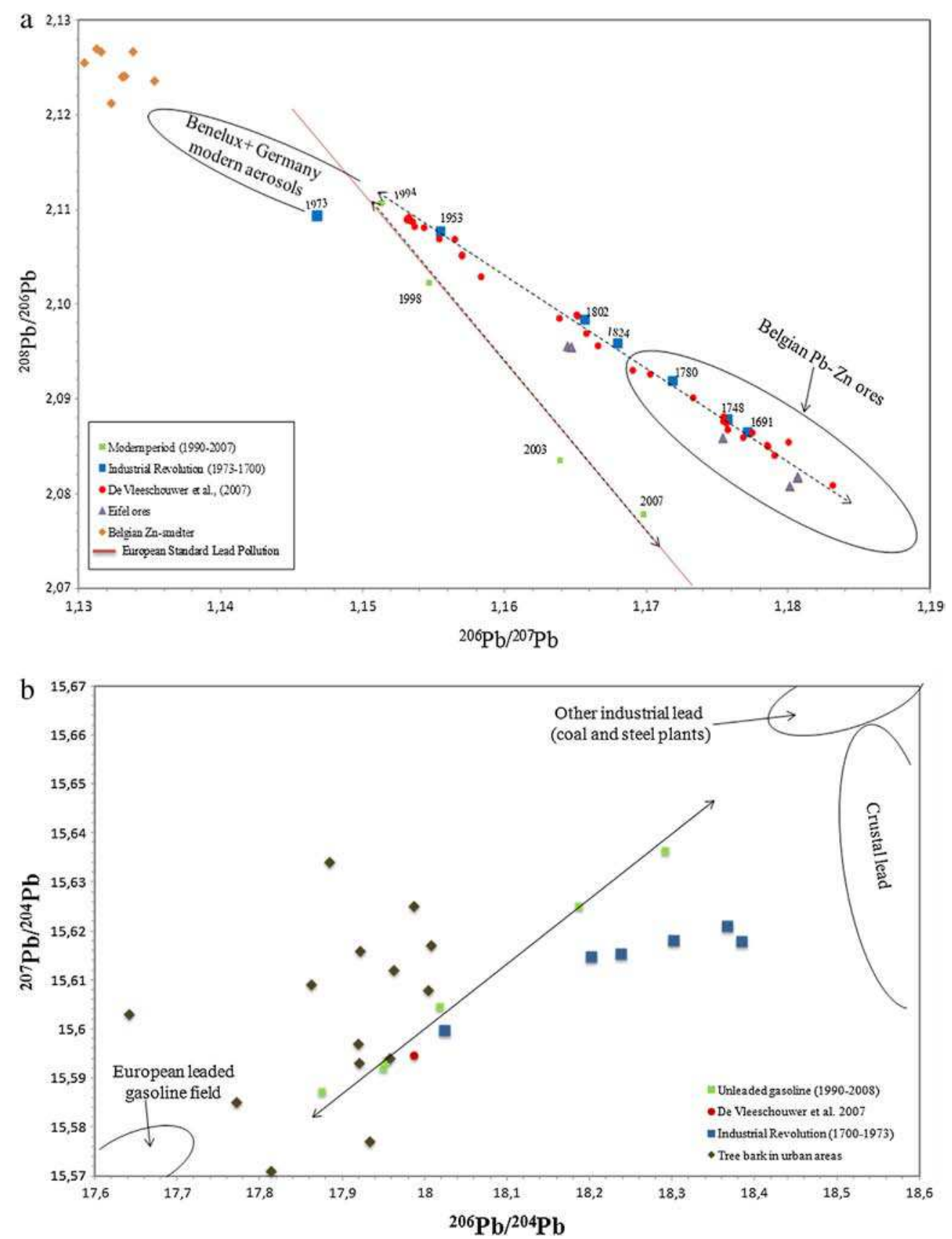

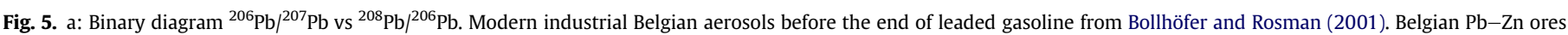

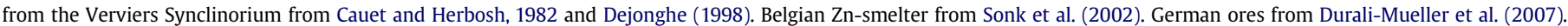

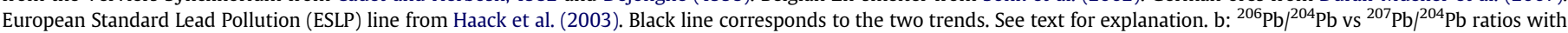

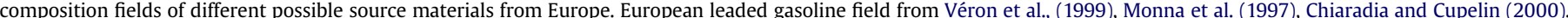

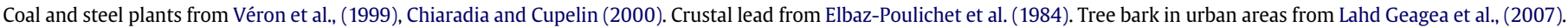

(1999) and more recently by Cloquet et al. (2006). As underlined by these authors, the second trend cannot be explained by the contribution of leaded gasoline. Instead, the new trend follows the European Standard Lead Pollution line ("ESLP"), which was defined by Haack et al. (2003), as "the average lead of the era of industrialization in Europe" (except Pb-gasoline), at least between the Alps and Scandinavia. The ESLP line can contain a mixture of sources that include crustal dust, emissions from lignite, coal, oil and gas power plants, from cement factories and domestic combustion as well as lead derived from geologically young ore deposit (Cloquet et al., 2006). In the Misten bog, this trend is clearly defined by the ${ }^{206} \mathrm{~Pb} /{ }^{204} \mathrm{~Pb}$ vs. ${ }^{207} \mathrm{~Pb} /{ }^{204} \mathrm{~Pb}$. Lead isotopic ratios of the recent samples are reported together with radiogenic industrial $\mathrm{Pb}$ sources from Europe (Fig. 5b). The recent samples are close to the mean composition of European metallurgical plants confirming the second linear trend. The topmost sample (dated AD 2003) from De Vleeschouwer et al. (2007) also fell within the trend indicated by ESLP. The Pb isotopic ratios of this study show that the Misten bog is influenced by a mixture of local and regional anthropogenic sources. Because the recent Misten samples fit with the EPSL line, we conclude that the Misten site represents a regional record of European pollution, at least for lead. 


\subsubsection{Cluster analysis}

To confirm the source interpretation made with $\mathrm{Pb}$ isotopes and to better evaluate the origin and behavior of trace metals in the Misten bog over the last 600 years, we carried out a Hierarchical Cluster Analysis (HCA) on the elemental geochemistry of the core $01 \mathrm{~W}$. This statistical approach allows the identification of any linear relationship between different trace metals AR.

For the core $01 \mathrm{~W}$, an HCA calculation, was first performed on all on all standardized trace metals AR using STATSTICA software. The obtained dendrograms identify three clusters of trace metals AR (Fig. 6):

- the first group AR includes $\mathrm{V}, \mathrm{Cr}, \mathrm{Co}, \mathrm{Ni}, \mathrm{Cu}, \mathrm{Cu}, \mathrm{Cr}, \mathrm{Al}, \mathrm{Ti}$ and $\mathrm{Sb}$

- the second group is defined by $\mathrm{AR}$ of $\mathrm{Pb}$ and $\mathrm{As}$

- the third group is composed of the potentially mobile elements $\mathrm{Zn}$ and $\mathrm{Cd}$.

The similarity cluster represents the degree of association between elements. The higher value on the similarity cluster suggests that the association between these elements is significant and their sources or behavior may be similar. The first and second groups are connected at a higher level (similarity >85\%). This relationship suggests common sources or common processes for these elements. The third group contains elements which may undergo post-depositional remobilization ( $\mathrm{Zn}$ and $\mathrm{Cd}$ ) as described earlier.

In order to have a chronological control on the statistical information provided by the data, a second HCA calculation on all trace metals AR was performed on successive intervals, i.e., early modern period ( $n=6$, from AD 1400 to 1700), Industrial Revolution and Leaded Gasoline Era ( $n=15$, AD 1700-1990) and the Recent period ( $n=14,1990-2008$ ) (Fig. 7a-c). The dendrogram for the early modern period displays three main clusters. Aluminum and $\mathrm{Ti}$ distributions are quite similar to some trace metals such as $\mathrm{Zn}, \mathrm{Pb}$ and $\mathrm{Cu}$. We think that this cluster traces emissions by $\mathrm{Pb}-\mathrm{Zn}$ ore mining and emissions of large dust particles. This contemporary increase agricultural and mining activity was already suggested by De Vleeschouwer et al. (2007, 2012).

During the Industrial Revolution, the dendrogram points to four groups (Fig. 7b). Groups 1, 2, and 3 are connected at a higher level (similarity $>80 \%$ ), which suggests that the association between these elements is very significant and their sources are similar. The main sources are associated with smelter and refinery production,

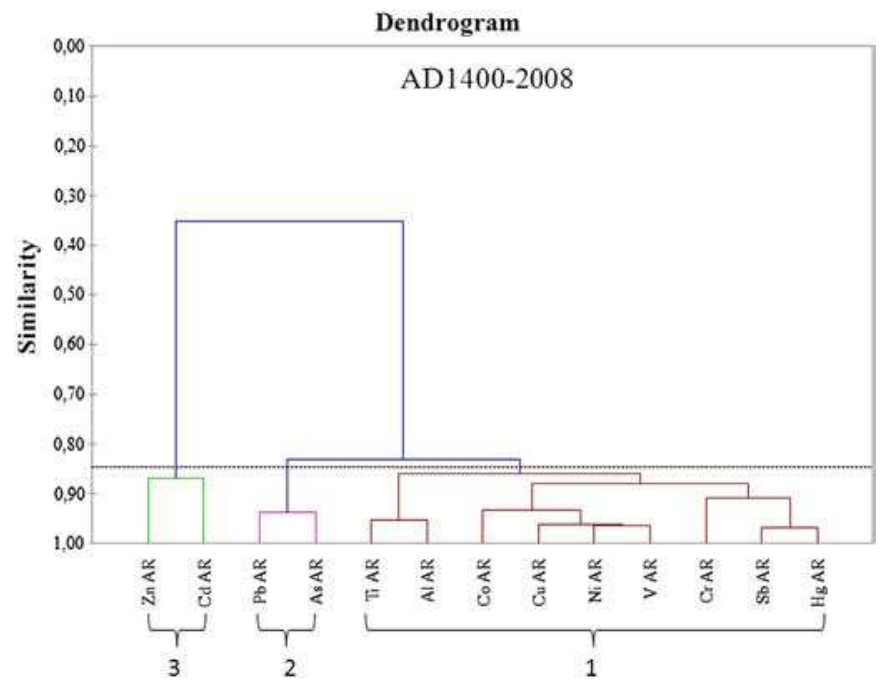

Fig. 6. Dendrogram for $\mathrm{AR}$ of $\mathrm{Cu}, \mathrm{Cr}, \mathrm{V}, \mathrm{Co}, \mathrm{Ni}, \mathrm{Hg}, \mathrm{Al}, \mathrm{Ti}, \mathrm{Pb}, \mathrm{Sb}, \mathrm{As}, \mathrm{Cd}$, and $\mathrm{Zn} \mathrm{AR}$ in the Misten bog over the last 600 years. and coal combustion. The fourth group includes AR of $\mathrm{Zn}$ and $\mathrm{Cd}$ may reflect a common source or mobility process. Accumulation rates of $\mathrm{Al}$ and $\mathrm{Ti}$ are similar to the trace metals AR (Fig. 7a-c), which may be explained by the presence of $\mathrm{Ti}$ and $\mathrm{Al}$ particles in anthropogenic sources. One cluster points out a common and unique source of $\mathrm{Co}, \mathrm{V}, \mathrm{Cr}$ and $\mathrm{Ni}$.

In addition, we perform a third HCA calculation for trace metals emissions measured in the Walloon region (Brahy, 2010; Fig. 7d) during the phasing out of lead in gasoline (1990-2008) and compare it with trace metals AR derived from the Misten data (Fig. 7c) for the same period (1990-2008). The dendrograms of trace metals AR (except $\mathrm{Zn}$ and $\mathrm{Cd}$ ) and TM emission are quite similar pointing out the validity of the statistical approach to estimate the common sources of immobile trace metals in peat cores.

\subsection{History of atmospheric deposition of trace metals in the Misten bog}

\subsubsection{Early modern period (from $A D 1400$ to 1700 )}

Enrichment factors and AR of trace metals increase slightly during this period (Figs. 3, 4). The Pb AR varies between 1 and $3 \mathrm{mg} \mathrm{m}^{-2} \mathrm{yr}^{-1}$, Cu AR $\left(0.01-0.09 \mathrm{mg} \mathrm{m}^{-2} \mathrm{yr}^{-1}\right)$, Sb AR (0.01$\left.0.02 \mathrm{mg} \mathrm{m}^{-2} \mathrm{yr}^{-1}\right)$, Ni AR $\left(0.03-0.11 \mathrm{mg} \mathrm{m}^{-2} \mathrm{yr}^{-1}\right)$, As AR (0.08$\left.0.18 \mathrm{mg} \mathrm{m}^{-2} \mathrm{yr}^{-1}\right), \mathrm{Cr}$ and V AR $\left(0.1-0.2 \mathrm{mg} \mathrm{m}^{-2} \mathrm{yr}^{-1}\right)$, Co AR (0.02-0.03 $\left.\mathrm{mg} \mathrm{m}^{-2} \mathrm{yr}^{-1}\right), \mathrm{Cd}$ AR $\left(0.1-0.2 \mathrm{mg} \mathrm{m}^{-2} \mathrm{yr}^{-1}\right), \mathrm{Zn} \mathrm{AR}(2-$ $8 \mathrm{mg} \mathrm{m}^{-2} \mathrm{yr}^{-1}$ ). Lead and $\mathrm{Zn}$ AR show an increase by a factor of 20100 compared to other trace metal ARs. This increase is represented by a shift in $\mathrm{Pb}$ isotope signatures $\left({ }^{206} \mathrm{~Pb} /{ }^{207} \mathrm{~Pb}=1.177\right.$ and ${ }^{208} \mathrm{~Pb} /{ }^{206} \mathrm{~Pb}=2.086$ ) which are in agreement with the field of the Belgian ores. The extraction of these ores during this period is reported in historical documents (Dejonghe, 1998).

\subsubsection{Industrial Revolution and unleaded gasoline (from $A D 1750$ to 1990 )}

Trace metals concentrations increase in parallel with a small decrease in the ${ }^{206} \mathrm{~Pb} /{ }^{207} \mathrm{~Pb}$ ratio. During this period, the local mining activity (Dejonghe, 1998) along with coal combustion and metal smelting added large quantities of anthropogenic aerosols to the atmosphere. Coal production started in Belgium in 1830 (Rutledge, 2011) and increased significantly to reach its maximum ( $\sim 30$ million metric tons $\mathrm{yr}^{-1}$ ) between $\mathrm{AD} 1927$ and 1955. Schmitz (1979) and Dejonghe (1998) showed that the Belgian $\mathrm{Zn}$ and $\mathrm{Pb}$ industry was established around $\mathrm{AD} 1830$ and the $\mathrm{Cu}$ industry around 1905 AD.

This strong increase in atmospheric pollution is recorded in the Misten bog by an increase of trace metal ARs by a factor of $8-15$ as compared to the period pre-1750. This increase in trace metal ARs is linked to the predominance of coal combustion and metal smelting in Belgium/Europe during this period (AD 1937-1954). After 1953, ${ }^{206} \mathrm{~Pb} /{ }^{207} \mathrm{~Pb}$ ratio drops to lower values (1.147) reflecting the higher importance of gasoline $\mathrm{Pb}$ contributions. This observation agrees with the observation of Von Storch et al. (2003), who proposed that $\mathrm{Pb}$ gasoline was the dominant anthropogenic source of $\mathrm{Pb}$ in 1965. The introduction of leaded gasoline increased from 1930 to a maximum in the 1970's (Von Storch et al., 2003). The progressive reduction of lead in gasoline started in 1972 (Von Storch et al., 2003).

The maximum EFs for $\mathrm{V}, \mathrm{Cr}, \mathrm{Ni}, \mathrm{Cu}, \mathrm{As}, \mathrm{Pb}$ and $\mathrm{Co} \mathrm{Sb}$ occurred between AD 1937 and 1995 (Fig. 3). Cobalt and Sb were only analyzed in core $01 \mathrm{~W}$. These enrichments are due to the important local and/or regional contamination level. Mostly critically, the bog is located at $20 \mathrm{~km}$ south of the $\mathrm{Pb}-\mathrm{Zn}$ ore deposits in eastern Belgium (Dejonghe, 1998) and $300 \mathrm{~km}$ from the industrial Ruhr Eifel Area. However, the highest EF values for $\mathrm{Zn}$ and $\mathrm{Cd}$ are observed during AD 1997-2004, which might be explained by remobilization, like plant uptake. 

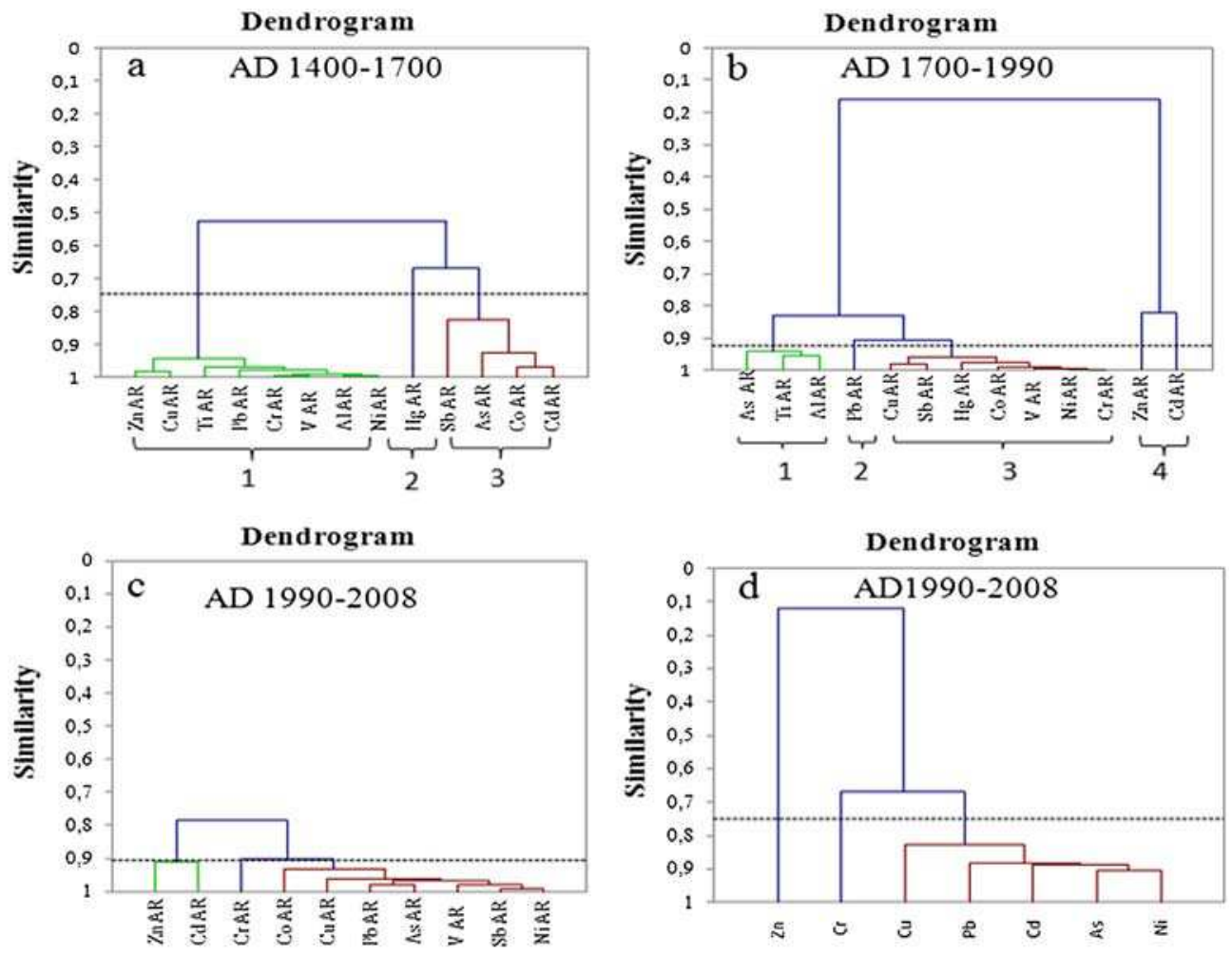

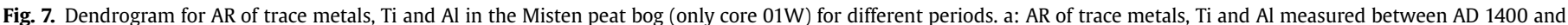

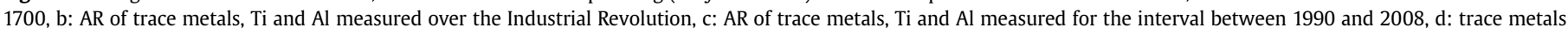
emissions measured in Walloon region between 1990 and 2008.

Between AD 1991 and 1996, all trace metal ARs, in core 01W, continued to increase (Fig. 4) to reach their maxima ( $\mathrm{Pb} A R=$ $116 \mathrm{mg} \mathrm{m}^{-2} \mathrm{yr}^{-1}$, Cu AR $=8 \mathrm{mg} \mathrm{m}^{-2} \mathrm{yr}^{-1}$, Sb AR $=1.5 \mathrm{mg} \mathrm{m}^{-2} \mathrm{yr}^{-1}$, Ni AR $=1.1 \mathrm{mg} \mathrm{m}^{-2} \mathrm{yr}^{-1}$, As AR $=2.5 \mathrm{mg} \mathrm{m}^{-2} \mathrm{yr}^{-1}, \mathrm{Cr} \mathrm{AR}=$ $8 \mathrm{mg} \mathrm{m}^{-2} \mathrm{yr}^{-1}, \mathrm{~V} \mathrm{AR}=6 \mathrm{mg} \mathrm{m}^{-2} \mathrm{yr}^{-1}, \mathrm{Co} \mathrm{AR}=0.5 \mathrm{mg} \mathrm{m}^{-2} \mathrm{yr}^{-1}, \mathrm{Cd}$
$\mathrm{AR}=90 \mathrm{mg} \mathrm{m}^{-2} \mathrm{yr}^{-1}$, and $\left.\mathrm{Zn} \mathrm{AR}=90 \mathrm{mg} \mathrm{m}^{-2} \mathrm{yr}^{-1}\right)$. However, in core $06 \mathrm{~W}$ trace metal ARs reach their maximum between 1930 and 1990 (Fig. 4b). This discrepancy is again explained by the fact that 01W was taken on a hummock while $06 \mathrm{~W}$ was taken between a hummock and a hollow, provoking difference in particle

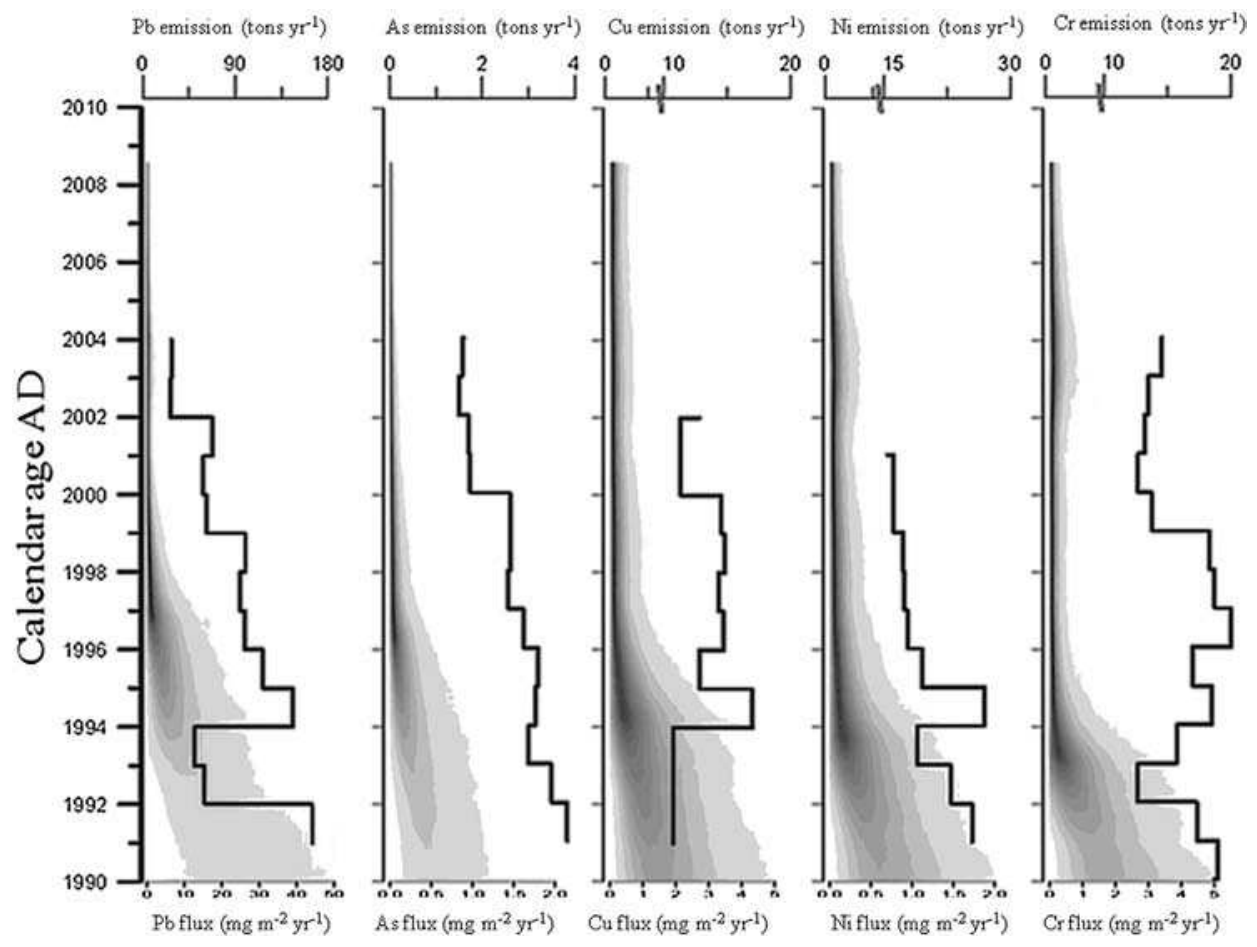

Fig. 8. Comparison between trace metal ARs in Misten bog (gray line) with trace metals emission in Walloon region (black line) from 1990 to 2008. 
deposition. The increase of trace metals AR in Misten peat samples is marked by a decrease in isotopic ratios ${ }^{206} \mathrm{~Pb} /{ }^{207} \mathrm{~Pb}$ and ${ }^{208} \mathrm{~Pb} /{ }^{206} \mathrm{~Pb}$. This shift is linked to the predominance of Belgian smelter and refinery production during that period.

Belgian smelter and refinery production $(\mathrm{Pb}, \mathrm{Cu}$ and $\mathrm{Zn}$ ) reached a maximum in AD 1978 (Schmitz, 1979), while coal consumption was at its maximum in Europe. From AD 1980 to 1990, coal consumption was about 22 million metric tons in Belgium, 50 million metric tons in France, and 500 million metric tons in Germany (Rutledge, 2011). Consequently, coal consumption, metallurgical activities and industrial development were the predominant source of pollution. Agricultural activities (e.g. pesticides and fertilizers) can also affect the concentrations of trace metals (Nziguheba and Smolders, 2008). Stevens and Van Wesemael (2008) show that the agricultural activities in Belgium increased steadily from 1890 to 1990 , and decreased after 1990 to present.

\subsubsection{Unleaded gasoline (from $A D 1990$ to 2008)}

In both cores, the trace metal ARs decrease from AD 1987-1995 to $A D$ 2006-2010, in parallel with an increase of the isotopic ratios ${ }^{206} \mathrm{~Pb} /{ }^{207} \mathrm{~Pb}$ and ${ }^{208} \mathrm{~Pb} /{ }^{206} \mathrm{~Pb}$. The reduction in trace metal ARs from 1987-1995 to 2006-2010 is very similar to the decrease in coal consumption in Europe and the trace metal atmospheric record in the Walloon region (Fig. 8). The industrial sector represents about $90 \%$ of total emissions of trace metals in the Walloon Region (Brahy, 2010). According to Brahy (2010), the trace metals emissions (Pb, $\mathrm{Cu}, \mathrm{Ni}, \mathrm{As}, \mathrm{Cr}, \mathrm{Cd}, \mathrm{Zn}$ ) in the Walloon region has decreased by $68 \%$ and their AR measured in Misten bog have decreased by $80-90 \%$ between 1990 and 2007. This reduction is explained in particular by the closure of steel companies, and also results from the disappearance of leaded gasoline and the progressive phasing out of coal combustion. Lead emissions have declined about 8 -fold between 1990 and 2007, following the banishment of leaded gasoline.

\section{Conclusion}

The Misten bog in Eastern Belgium provides a high resolution record of the trace metals and $\mathrm{Pb}$ isotope signatures over the last 600 years. The general agreement in trace metals concentration profiles in the cores $01 \mathrm{~W}$ and $06 \mathrm{~W}$ suggest that all investigated trace metals, except $\mathrm{Zn}$ and $\mathrm{Cd}$, are conserved in the Misten bog. This study shows the utility of taking more than one core to show the heterogeneity in peat accumulation and to study the mobility of trace metals. For all trace metals, the maximum AR is found near the surface of the bog, in peat layers dated AD 19301995.

During the Industrial Revolution our cluster analysis and $\mathrm{Pb}$ isotopic ratios indicate diverse sources of atmospheric contamination (coal, industrial, steel production, road dust) for all studied trace metals. The upper Misten section is in agreement with measured emissions in the Walloon region.

The history of trace metals in the Misten bog is in agreement with other European records, reflecting the influence of regional European pollution. This study shows that ombrotrophic bog may be an excellent and accurate archive of some trace metals $(\mathrm{V}, \mathrm{Cr}, \mathrm{Co}$, $\mathrm{Ni}, \mathrm{Cu}, \mathrm{As}, \mathrm{Pb}$ and $\mathrm{Sb}$ ).

\section{Acknowledgments}

This study was funded by the Walloon Region and the FNRS. M. Allan received funding through a PhD grant from the government of Syria. We also thank Gunnar Mallon, Mona Court-Picon, Freddy Dambon, Michel Mathijs and Maurice Streel for their help with the peat sampling, as well as people at the OMP laboratory for ICP-MS analyses and discussion. W. Shotyk (University of Heidelberg) is warmly thanked for loaning his Ti-Wardenaar corer and for having let us use the peat cutting as well as the ultraclave microwave facilities at the IES (University of Heidelberg, Germany). We thank Konrad Tudyka and Agnieszka Wiszniowska for their help with the ${ }^{14} \mathrm{C}$ sample preparation. Pascal Mertes (DNF-Belgian Forest and Nature Ministry) is also acknowledged for providing us with the official authorization for coring the Misten bog. The WD-XRF data acquisition was made possible by Richard Bindler (Umeå University) through a research grant from the Kempe Foundation, which also provided a post-doc fellowship to F. De Vleeschouwer in 2010.

\section{References}

Aaby, B., 1976. Cyclic climatic variations in climate over the past 5,500 yr reflected in raised bogs. Nature 263 (5575), 281-284

Allan, M., Le Roux, G., Sonke, J., Piotrowska, N., Streel, M., Fagel, N., 2012. Intra-site variability in reconstructing historical atmospheric mercury deposition in Western Europe: the Misten peat bog (Hautes Fagnes - Belgium). Science of the Total Environment 442, 290-301.

Allen, A.G., Nemitz, E., Shi, J.P., Harrison, R.M., Greenwood, J.C., 2001. Size distributions of trace metals in atmospheric aerosols in the United Kingdom. Atmospheric Environment 35, 4581-4591.

Bacon, J.R., Jones, K.C., McGrath, S.P., Johnston, A.E., 1996. Isotopic character of lead deposited from the atmosphere at a grassland site in the United Kingdom since 1860. Environmental Science \& Technology 30, 2511-2518.

Baeyens, W., Dedeeurwaerder, H., 1990. Particulate trace metals above the Southern Bight of the North Sea-1. Analytical procedures and average aerosol concentrations. Atmospheric Environment 25, 293-304.

Bergkvist, B., Folkeson, L., Berggren, D., 1989. Fluxes of $\mathrm{Cu}, \mathrm{Zn}, \mathrm{Pb}, \mathrm{Cd}, \mathrm{Cr}$, and $\mathrm{Ni}$ in temperate forest ecosystems. Water, Air, \& Soil Pollution 47, 217-228.

Blaauw, M., Christen, J.A., 2011. Flexible paleoclimate age-depth models using an autoregressive gamma process. Bayesian Analysis 6, 457-474.

Bollhöfer, A., Rosman, K.J.R., 2001. Lead isotopic ratios in European atmospheric aerosols. Physics and Chemistry of the Earth, Part B: Hydrology, Oceans and Atmosphere 26 (10), 835-838.

Brahy, V., 2010. Tableau de bord de l'environnement wallon. Service Public de Wallonie, Liège, 232 p. (in French). http://etat.environnement.wallonie.be/ index.php?page=le-tableau-de-bord-2010.

Buschmann, J., Kappeler, A., Lindauer, U., Kistler, D., Berg, M., Sigg, L., 2006. Arsenite and arsenate binding to dissolved humic acids: influence of $\mathrm{pH}$, type of humic acid and aluminium. Environmental Science \& Technology 40, 6015-6020.

Cauet, S.W.D., Herbosh, A., 1982. Genetic study of Belgian lead zinc mineralizations in carbonate environments through lead isotope geochemistry. Bulletin du BRGM 3, 29-41.

Cerqueira, C.S., Romão, L.P.C., Fraga, L.E., Simões, M.L., Hammer, P., Lead, J.R Mangoni, A.P., Mangrich, A.S., 2012. Spectroscopic characterization of reduction and removal of chromium (VI) by tropical peat and humin. Fuel 91, 141-214.

Chiaradia, M., Cupelin, F., 2000. Behaviour of airborne lead and temporal variations of its source effects in Geneva (Switzerland): comparison of anthropogenic versus natural processes. Atmospheric Environment 34, 959-971.

Cloquet, C., Carignan, J., Libourel, G., 2006. Atmospheric pollutant dispersion around an urban area using trace metal concentrations and $\mathrm{Pb}$ isotopic compositions in epiphytic lichens. Atmospheric Environment 40 (3), 574-587.

Cloy, J.M., Farmer, J.G., Graham, M.C., MacKenzie, A.B., Cook, G.T., 2005 A comparison of antimony and lead profiles over the past 2500 years in Flanders Moss ombrotrophic peat bog, Scotland. Journal of Environmental Monitoring 7, 1137-1147.

Cloy, J.M., Farmer, J.G., Graham, M.C., MacKenzie, A.B., 2009. Retention of As and Sb in ombrotrophic peat bogs: records of $\mathrm{As}, \mathrm{Sb}$ and $\mathrm{Pb}$ deposition at four Scottish sites. Environmental Science \& Technology 43, 1756-2176.

Damman, A.W.H., 1978. Distribution and movement of elements in ombrotrophic peat bogs. Oikos 30, 480-495.

Damman, A.W.H., 1986. Hydrology, development, and biogeochemistry of ombrogenous peat bogs with special reference to nutrient relocation in western Newfoundland bog. Canadian Journal of Botany 64, 384-394.

De Vleeschouwer, F., Gérard, L., Goormaghtigh, C., Mattielli, N., Le Roux, G., Fagel, N. 2007. Atmospheric lead and heavy metal pollution records from a Belgian peat bog spanning the last two millennia: human impact on a regional to global scale. Science of the Total Environment 377, 282-295.

De Vleeschouwer, F., Fagel, N., Cheburkin, A., Pazdur, A., Sikorski, J., Mattielli, N., 2009. Anthropogenic impacts in North Poland over the last 1300 years - a record of $\mathrm{Pb}, \mathrm{Zn}, \mathrm{Cu}, \mathrm{Ni}$ and $\mathrm{S}$ in an ombrotrophic peat bog. Science of the Total Environment 407, 5674-5684.

De Vleeschouwer, F., Sikorski, J., Fagel, N., 2010a. Development of lead 210 measurement in peat using polonium extraction. A comparison of techniques. Geochronometria 36, 1-8.

De Vleeschouwer, F., Luthers, C., Streel, M., 2010b. Recherche d'intérêt général et pluridisciplinaire relative aux modalités de l'accumulation récente de la tourbe dans la tourbière ombrogene du Misten (Hautes-Fagnes) en relation avec les changements climatiques et les effets des activités humaines. In: La Cellule Etat 
de l'environnement wallon, 98 p. (in French). http://etat.environnement. wallonie.be/index.php?page $=$ etudes-detaillees.

De Vleeschouwer, F., Le Roux, G., Shotyk, W., 2010c. Peat as an archive of atmospheric metal pollution: the example of $\mathrm{Pb}$ in Europe. In: Jackson, S. Charman, D. (Eds.), Peatland. Special Issue of PAGES Newsletter, April 2010.

De Vleeschouwer, F., Luthers, C., Mauquoy, D., Wastiaux, C., Le Roux, G., Moschen, R. Pawlyta, J., Pazdur, A., Sikorski, J., Piotrowska, N., 2012. Multiproxy paleoenvironmental study in the Misten bog (East Belgium) during the last millenium. Quaternary International 268, 44-57.

Dejonghe, L., 1998. Zinc-lead deposits of Belgium. Ore Geology Reviews 12, 329354.

Durali-Mueller, S., Brey, G.P., Wigg-Wolf, D., Lahaye, Y., 2007. Roman lead mining in Germany: its origin and development through time deduced from lead isotope provenance studies. Journal of Archaeological Science 34 (10), 1555-1567.

Elbaz-Poulichet, F., Holliger, P., Huang, W.W., Martin, J.M., 1984. Lead cycling in estuaries, illustrated by the Gironde estuary, France. Nature 308, 409-411.

Farmer, J.G., Eades, L.J., Atkins, H., Chamberlain, D.F., 2002. Historical trends in the lead isotopic composition of archival Sphagnum mosses from Scotland (18382000). Environmental Science \& Technology 36, 152-157.

Farmer, J.G., Anderson, P., Cloy, J.M., Graham, M.C., MacKenzie, A.B., Cook, G.T., 2009. Historical accumulation rates of mercury in four Scottish ombrotrophic peat bogs over the past 2000 years. Science of the Total Environment 407 (21), 5578-5588.

Galer, S.J.G., Abouchami, W., 1998. Practical application of lead triple spiking for correction of instrumental mass discrimination. In: 8th Goldschmidt Conference, Mineralogical Magazine, 62A, pp. 491-492.

Givelet, N., Le Roux, G., Cheburkin, A., Chen, B., Frank, J., Goodsite, M., Kempter, H., Krachler, M., Noernberg, T., Rausch, N., Rheinberger, S., Roos-Barraclough, F. Sapkota, A., Scholz, C., Shotyk, W., 2004. Suggested protocol for collecting handling and preparing peat cores and peat samples for physical, chemical, mineralogical and isotopic analyses. Journal of Environmental Monitoring 6 (5), $481-492$.

Gore, A.J.P., 1983. Ecosystems of the World, vols. 4A and 4B. Mires: Swamp, Bog, Fen and Moor. Amsterdam: Elsevier.

Haack, U.K., Heinrichs, H., Gutsche, F.H., Plessow, K., 2003. On the isotopic composition of $\mathrm{Pb}$ in soil profiles of Northern Germany: evidence for pollutant $\mathrm{Pb}$ from a continent-wide mixing system. Water, Air, \& Soil Pollution 150, 113134.

Hong, S.M., Candelone, J.P., Patterson, C.C., Boutron, C.F., 1994. Greenland ice evidence of hemispheric lead pollution two millennia ago by Greek and Roman civilizations. Science 265, 1841-1843.

Injuk, J., Otten, Ph., Laane, R., Maenhaut, W., Van Grieken, R., 1992. Atmospheric concentrations and size distribution of aircraft-sampled $\mathrm{Cd}, \mathrm{Cu}, \mathrm{Pb}$ and $\mathrm{Zn}$ ove the Southern Bight of the North Sea. Atmospheric Environment 26, 2499-2508.

Kabata-Pendias, A., 2001. Trace Elements in Soils and Plants, third ed. CRC Press LLC Boca Raton.

Kempter, H., Frenzel, B., 1999. The local nature of anthropogenic emission sources on the elemental content of nearby ombrotrophic peat bogs, Vulkaneifel, Germany. Science of the Total Environment 241, 117-128.

Kilian, M.R., van der Plicht, J., Van Geel, B., 1995. Dating raised bogs: new aspects of AMS ${ }^{14} \mathrm{C}$ wiggle matching, a reservoir effect and climatic change. Quaternary Science Reviews 14, 959-966.

Krachler, M., Mohl, C., Emons, H., Shotyk, W., 2002. Analytical procedures for the determination of selected trace elements in peat and plant samples by induc tively coupled plasma mass spectrometry. Spectrochimica Acta Part B: Atomic Spectroscopy 57, 1277-1289.

Krachler, M., Mohl, C., Emons, H., Shotyk, W., 2003. Atmospheric deposition of V, Cr and $\mathrm{Ni}$ since $12,37014 \mathrm{C}$ yr BP recorded by a Swiss peat bog profile. Environmental Science \& Technology 37, 2658-2667.

Laaksoharju, M., Skarman, C., Skarman, E., 1999. Multivariate mixing and mass balance (M3) calculation, a new tool for decoding hydrogeochemical information. Applied Geochemistry 14, 861-871.

Lahd Geagea, M., Stille, P., Millet, M., Perrone, Th., 2007. REE characteristics and Pb, $\mathrm{Sr}$ and Nd isotopic compositions of steel plant emissions. Science of the Total Environment 373, 404-419.

Le Roux, G., Marshall, W.A., 2011. Constructing recent peat accumulation chronologies using atmospheric fall-out radionuclides. Mires and Peat 7. Art. 8. Online: http://www.mires-and-peat.net/map07/map_07_08.htm.

Le Roux, G., Aubert, D., Stille, P., Krachler, M., Kober, B., Cheburkin, A., Bonani, G., Shotyk, W., 2005. Recent atmospheric Pb deposition at a rural site in southern Germany assessed using a peat core and snowpack, and comparison with other archives. Atmospheric Environment 39 (36), 6790-6801.

Livett, A.E., Lee, J.A., Tallis, J.H., 1979. Lead Zinc and Copper analyses of British blanket peats. Journal of Ecology 67, 865-891.

MacKenzie, A.B., Logan, E.M., Cook, G.T., Pulford, I.D., 1998. Distributions, inventories and isotopic composition of lead in $210 \mathrm{~Pb}$-dated peat cores from contrasting biogeochemical environments: implications for lead mobility. Science of the Total Environment 223, 25-35.

Martinez-Cortizas, A., Pontevedra-Pombal, X., Novoa-Munoz, J.C., Garcia-Rodeja, E. 1997. Four thousand years of atmospheric $\mathrm{Pb}, \mathrm{Cd}$ and $\mathrm{Zn}$ deposition recorded by the ombrotrophic peat bog of Penido Vello (Northwestern Spain). Water, Air, \& Soil Pollution 100, 387-403.

Mauquoy, D., van Geel, B., Blaauw, M., Speranza, A., van der Plicht, J., 2004. Changes in solar activity and Holocene climatic shifts derived from ${ }^{14} \mathrm{C}$ wiggle-match dated peat deposits. The Holocene 14, 45-52.
Monna, F., Lancelot, J., Croudace, I.W., Cundy, A.B., Lewis, J.T., 1997. Pb isotopic composition of airborne particulate material from France and the southern United Kingdom: implications for Pb pollution sources in urban areas. Environmental Science \& Technology 31, 2277-2286.

Nieminen, T.M., Ukonmaanaho, L., Shotyk, W., 2002. Enrichments of Cu, Ni, Zn, Pb and $\mathrm{As}$ in an ombrotrophic peat bog near a Cu-Ni smelter in Southwest Finland. Science of the Total Environment 292, 81-89.

Norton, S.A., Evans, G.C., Kahl, J.S., 1998. Comparison of $\mathrm{Hg}$ and $\mathrm{Pb}$ fluxes to hummocks and hollows of ombrotrophic Big Heath bog and to nearby Sargent Mt. Pond, Maine, USA. Water, Air, \& Soil Pollution 100, 271-286.

Novak, M., Pacherova, P., 2008. Mobility of trace metals in pore waters of two Central European peat bogs. Science of the Total Environment 394 (2-3), 331-337.

Novak, M., Zemanova, L., Voldrichova, M., Adamova, M., Pacherova, P., Komarek, A., Krachler, M., Prechova, E., 2011. Experimental evidence for mobility/ immobility of metals in peat. Environmental Science \& Technology 45 (17), 7180-7187.

Nriagu, J.O., 1979. Global inventory of natural and anthropogenic emissions of trace metals to the atmosphere. Nature $279,409-411$.

Nriagu, J.O., 1996. A history of global metal pollution. Science 272, 223-224.

Nziguheba, G., Smolders, E., 2008. Inputs of trace elements in agricultural soils via phosphate fertilizers in European countries. Science of the Total Environment 390, 53-57.

Oldfield, F., Richardson, N., Appleby, P.G., 1995. Radiometric dating $\left({ }^{210} \mathrm{~Pb},{ }^{137} \mathrm{Cs}\right.$, ${ }^{241} \mathrm{Am}$ ) of recent ombrotrophic peat accumulation and evidence for changes in mass balance. The Holocene 5 (2), 141-148.

Olid, C., Garcia-Orellana, J., Martínez-Cortizas, A., Masqué, P., Peiteado-Varela, E., Sanchez-Cabeza, J.A., 2010. Multiple site study of recent atmospheric metal (Pb, $\mathrm{Zn}$ and $\mathrm{Cu}$ ) deposition in the NW Iberian Peninsula using peat cores. Science of the Total Environment 408, 5540-5554.

Pacyna, J.M., Pacyna, E.G., 2001. An assessment of global and regional emissions of trace metals to the atmosphere from anthropogenic sources worldwide. Environmental Reviews 9, 269-298.

Pacyna, E.G., Pacyna, J.M., Fudala, J., Strzelecka-Jastrzab, E., Hlawiczka, S., Panasiuk, D., Nitter, S., Pregger, T., Pfeiffer, H., Friedrich, R., 2007. Current and future emissions of selected heavy metals to the atmosphere from anthropogenic sources in Europe. Atmospheric Environment 41, 8557-8566.

Piotrowska, N., De Vleeschouwer, F., Sikorski, J., Pawlyta, J., Fagel, N., Le Roux, G., Pazdur, A., 2010. Intercomparison of radiocarbon bomb pulse and $210 \mathrm{~Pb}$ age models. A study in a peat bog core from North Poland. Nuclear Instruments and Methods in Physics Research Section B: Beam Interactions with Materials and Atoms 268 (7-8), 1163-1166.

Piotrowska, N., Blaauw, M., Mauquoy, D., Chambers, F.M., 2011. Constructing deposition chronologies for peat deposits using radiocarbon dating. Mires and Peat $10,1-14$

Pontevedra-Pombal, X., Mighall, T.M., Nóvoa-Muñoz, J.C., Peiteado-Varela, E., Rodríguez-Racedo, J., García-Rodeja, E., Martínez-Cortizas, A., 2013. Five thousand years of atmospheric $\mathrm{Ni}, \mathrm{Zn}$, As, and $\mathrm{Cd}$ deposition recorded in bogs from NW Iberia: prehistoric and historic anthropogenic contributions. Journal of Archaeological Science 40, 764-777.

Rausch, N., Ukonmaanaho, L., Nieminen, T., Krachler, M., Shotyk, W., 2005a. Porewater evidence of metal $(\mathrm{Cu}, \mathrm{Ni}, \mathrm{Co}, \mathrm{Zn}, \mathrm{Cd})$ mobilization in an acidic, ombrotrophic bog impacted by a smelter, Harjavalta, Finland and comparison with reference sites. Environmental Science \& Technology 39, 8207-8213.

Rausch, N., Nieminen, T., Ukonmaanaho, L., Le Roux, G., Krachler, M. Cheburkin, A.K., Bonani, G., Shotyk, W., 2005b. Comparison of atmospheric deposition of copper, nickel, cobalt, zinc and cadmium recorded by Finnish peat cores with monitoring data and emission records. Environmental Science \& Technology 39 (16), 5989-5998.

Renberg, I., Wik-Persson, M., Emteryd, O., 1994. Pre-industrial atmospheric lead contamination detected in Swedish lake sediments. Nature 368, 323-326.

Renberg, I., Bindler, R., Brannvall, M.L., 2001. Using the historical atmospheric leaddeposition record as a chronological marker in sediment deposits in Europe. The Holocene 11, 511-516.

Renson, V., Fagel, N., Mattielli, N., Nekrassoff, S., Streel, M., De Vleeschouwer, F. 2008. Roman road pollution assessed by elemental and lead isotope geochemistry in East Belgium. Applied Geochemistry 23, 3253-3266.

Rothwell, J.J., Taylor, K.G., Ander, E.L., Evans, M.G., Allott, T.E.H., 2009. Arsenic retention and release in ombrotrophic peatlands. Science of the Total Environment 407, 1405-1417.

Rothwell, J.J., Taylor, K.G., Chenery, S.R.N., Cundy, A.B., Allott, T.E.H., 2010. Storage and behavior of $\mathrm{As}, \mathrm{Sb}, \mathrm{Pb}$ and $\mathrm{Cu}$ in ombrotrophic peat bogs under contrasting water table conditions. Environmental Science \& Technology 44, 8497-8502

Rutledge, D., 2011. Estimating long-term world coal production with logit and probit transforms. Internal Journal of Coal Geology 85, 23-31.

Schmitz, C., 1979. World Non-ferrous Metal Production and Prices. 1700-1976. Routledge Chapman and Hall.

Shirahata, H., Elias, R.W., Patterson, C.C., 1980. Chronological variations in concentrations and isotopic compositions of anthropogenic atmospheric lead in sediments of a remote subalpine pond. Geochimica Cosmochimica Acta 49, 149-162.

Shotyk, W., Weiss, D., Appleby, P.G., Cheburkin, A.K., Frei, R., Gloor, M., et al., 1998. History of atmospheric lead deposition since $12,370{ }^{14} \mathrm{C}$ yr BP recorded in a peat bog profile, Jura Mountains, Switzerland. Science 281, 1635-1640. 
Shotyk, W., Le Roux, G., 2005. Biogeochemistry and cycling of lead. In: Sigel, A., Sigel, H., Sigel, R.K.O. (Eds.), Biogeochemical Cycles of the Elements, vol. 43. M. Dekker.

Shotyk, W., Cheburkin, K., Appleby, P.G., Fankhauser, A., Kramers, J.D., 1996. Two thousand years of atmospheric arsenic, antimony, and lead deposition recorded in an ombrotrophic peat bog profile, Jura Mountains, Switzerland. Earth and Planetary Science Letters 145 (1-4), E1-E7.

Shotyk, W., Blaser, P., Grünig, A., Cheburkin, A.K., 2000. A new approach for quantifying cumulative, anthropogenic, atmospheric lead deposition using peat cores from bogs: $\mathrm{Pb}$ in eight Swiss peat bog profiles. Science of the Total Environment 249 (1-3), 281-295.

Shotyk, W., Weiss, D., Kramers, J.D., Frei, R., Cheburkin, A.K., Gloor, M., Reese, S., 2001 Geochemistry of the peat bog at Etang de la Gruère, Jura Mountains, Switzerland, and its record of atmospheric $\mathrm{Pb}$ and lithogenic trace metals (Sc, Ti, Y, Zr, and REE) since $12370{ }^{14} \mathrm{C}$ yr BP. Geochimica Cosmochimica Acta 65 (14), 2337-2360.

Shotyk, W., Krachler, M., Martinez-Cortizas, A., Cheburkin, A.K., Emons, H., 2002. A peat bog record of natural, pre-anthropogenic enrichments of trace elements in atmospheric aerosols since $12370{ }^{14} \mathrm{C}$ yr BP, and their variation with Holocene climate change. Earth and Planetary Science Letters 199 (1-2), 21-37.

Shotyk, W., Goodsite, M.E., Roos-Barraclough, F., Frei, R., Heinemeier, J., Asmund, G. Lohse, C., Hansen, T.C., 2003. Anthropogenic contributions to atmospheric Hg, $\mathrm{Pb}$ and As accumulation recorded by peat cores from southern Greenland and Denmark dated using the $14 \mathrm{C}$ "bomb pulse curve". Geochimica Cosmochimica Acta 67 (21), 3991-4011.

Shotyk, W., Krachler, M., Chen, B., 2004. Antimony in recent peat from Switzerland and Scotland: comparison with natural background values (5,320 to 8,020 $14 \mathrm{C}$ yr $\mathrm{BP})$, correlation with $\mathrm{Pb}$, and implications for the global atmospheric Sb cycle. Global Biogeochemical Cycles 18. http://dx.doi.org/10.1029/2003GB002113. GB1016.

Shotyk, W., Goodsite, M.E., Roos-Barraclough, F., Givelet, N., Le Roux, G., Weiss, D., Chemburkin, A.K., Knudden, K., Heinemeier, J., Van Der Knaap, W.O. Norton, S.A., Lohse, C., 2005. Accumulation rates and predominant atmospheric sources of natural and anthropogenic $\mathrm{Hg}$ and $\mathrm{Pb}$ on the Faroe Islands. Geochimica Cosmochimica Acta 69 (1), 1-17.

Shotyk, W., Krachler, M., Chen, B., 2005a. Lithogenic, oceanic and anthropogenic sources of atmospheric Sb to a maritime blanket bog, Myanmar, Faroe Islands. Journal of Environmental Monitoring 7, 1148-1154.
Sikorski, J., Bluszcz, A., 2008. Application of $\alpha$ and $\gamma$ spectrometry in the ${ }^{210} \mathrm{~Pb}$ method to model sedimentation in artificial retention reservoir. Geochronometria 31, 65-75.

Sonk, J.E., Hoogewerff, J.A., Van, D.L., Sieger, R., Vangronsveld, J., 2002. A chemica and mineralogical reconstruction of Zn-smelter emissions in the Kempen region (Belgium), based on organic pool sediment cores. Science of the Total Environment 292, 101-109.

Stevens, A., Van Wesemael, B., 2008. Soil organic carbon dynamics at regional scale as influenced by land use history: a case study in forest soils from southern Belgium. Soil Use and Management 24, 69-79.

Thirlwall, M.F., 2002. Multicollector ICP-MS analysis of $\mathrm{Pb}$ isotopes using a ${ }^{207} \mathrm{~Pb}-$ ${ }^{204} \mathrm{~Pb}$ double spike demonstrates up to $400 \mathrm{ppm} / \mathrm{amu}$ systematic errors in $\mathrm{Tl}$ normalization. Chemical Geology 184 (3-4), 255-279.

Ukonmaanaho, L., Nieminen, T.M., Rausch, N., Shotyk, W., 2004. Heavy metal and arsenic profiles in ombrogenous peat cores from four differently loaded areas in Finland. Water, Air, \& Soil Pollution 158, 277-291.

Véron, A., Flament, P., Bertho, M.L., Alleman, L., Flegal, R., Hamelin, B., 1999. Isotopic evidence of pollutant lead sources in Northwestern France. Atmospheric Environment 33 (20), 3377-3388.

Von Storch, H. Costa-Cabral, M., Hagner, C., Feser, F, Pacyna, J., Pacyna, E. Kolb, S., 2003. Four decades of gasoline lead emissions and control policies in Europe: a retrospective assessment. Science of the Total Environment 311 (1-3), 151-176.

Wardenaar, E., 1987. A new hand tool for cutting peat profiles. Revue Canadienne de Botanique 65 (8), 1771-1772.

Wastiaux, C., Schumacker, R., 2003. Topographie de surface et de subsurface des zones tourbeuses des réserves naturelles domaniales des Hautes-Fagnes. Convention C60 entre le Ministère de la Région Wallonne. Direction générale des Ressources naturelles et de l'Environnement, et l'Université de Liège. Unpublished report, 52 p. +annexes. (in French).

Weiss, D.J., Shotyk, W., Schafer, J., Loyall, U., Grollimund, E., Gloor, M., 1999. Microwave digestion of ancient peat and lead determination by voltammetry Fresenius Journal of Analytical Chemistry 363, 300-305.

Weiss, D., Shotyk, W., Boyle, A.E., Kramers, D.J., Appleby, P.G., Cheburkin, A.K., 2002 Comparative study of the temporal evolution of atmospheric lead deposition in Scotland and eastern Canada using blanket peat bog. Science of the Tota Environment 292, 7-18. 